NBER WORKING PAPER SERIES

\title{
FAST-FOOD RESTAURANT ADVERTISING ON TELEVISION AND ITS INFLUENCE ON CHILDHOOD OBESITY
}

\author{
Shin-Yi Chou \\ Inas Rashad \\ Michael Grossman \\ Working Paper 11879 \\ http://www.nber.org/papers/w11879 \\ NATIONAL BUREAU OF ECONOMIC RESEARCH \\ 1050 Massachusetts Avenue \\ Cambridge, MA 02138 \\ December 2005
}

Research for this paper was supported by grant number 1R01 DK54826 from the National Institute of Diabetes and Digestive and Kidney Diseases to the National Bureau of Economic Research. Preliminary versions of the paper were presented at the Fifth World Congress of the International Health Economics Association, the 2004 Eastern Economics Association Conference, the 2004 Southern Economic Association Conference, the 2005 Chinese Economists Society Convention, and at seminars at Lehigh University and the Centers for Disease Control and Prevention. We wish to thank the participants in these conferences and seminars for helpful comments and suggestions. This paper has not undergone the review accorded official NBER publications; in particular, it has not been submitted for approval by the Board of the Directors. Any opinions expressed are those of the authors and not those of NIDDKD or NBER. The views expressed herein are those of the author(s) and do not necessarily reflect the views of the National Bureau of Economic Research.

(C)2005 by Shin-Yi Chou, Inas Rashad, and Michael Grossman. All rights reserved. Short sections of text, not to exceed two paragraphs, may be quoted without explicit permission provided that full credit, including (C) notice, is given to the source. 
Fast-Food Restaurant Advertising on Television and Its Influence on Childhood Obesity Shin-Yi Chou, Inas Rashad, and Michael Grossman

NBER Working Paper No. 11879

December 2005

JEL No. I10, I12

\begin{abstract}
$\underline{\text { ABSTRACT }}$
Childhood obesity around the world, and particularly in the United States, is an escalating problem that is especially detrimental as its effects carry on into adulthood. In this paper we employ the 1979 Child-Young Adult National Longitudinal Survey of Youth and the 1997 National Longitudinal Survey of Youth to estimate the effects of fast-food restaurant advertising on children and adolescents being overweight. The advertising measure used is the number of hours of spot television fast-food restaurant advertising messages seen per week. Our results indicate that a ban on these advertisements would reduce the number of overweight children ages 3-11 in a fixed population by 10 percent and would reduce the number of overweight adolescents ages 12-18 by 12 percent. The elimination of the tax deductibility of this type of advertising would produce smaller declines of between 3 and 5 percent in these outcomes but would impose lower costs on children and adults who consume fast food in moderation because positive information about restaurants that supply this type of food would not be banned completely from television.

Shin-Yi Chou

Department of Economics

College of Business and Economics

Lehigh University

621 Taylor Street

Bethlehem, PA 18015-3117

and NBER

syc@lehigh.edu

Inas Rashad

Department of Economics

Georgia State University

P.O. Box 3992

Atlanta, GA 30302-3992

irashad@gsu.edu

Michael Grossman

City University of New York Graduate Center 365 Fifth Avenue, $5^{\text {th }}$ Floor

New York, NY 10016-4309

and NBER

mgrossman@gc.cuny.edu
\end{abstract}




\section{INTRODUCTION}

Childhood obesity around the world, and particularly in the United States, is an escalating problem that has received much attention of late. In less than thirty years, the prevalence of overweight children and adolescents in America has more than doubled. In the 1963-1970 period, 4 percent of children aged 6 to 11 years and 5 percent of adolescents aged 12 to 19 were defined as being overweight. The percentage of children who are overweight has more than tripled by 1999, reaching 13 percent. For adolescents, the incidence of overweight has nearly tripled in the same period, reaching 14 percent (Centers for Disease Control 2001).

Finding the causes of this dramatic increase in obesity among children and adolescents is an important input in designing prevention policies. On the simplest level, weight gain is caused by more energy intake than energy expenditure over a long period of time. The problem of energy imbalance is not purely due to genetics, since our genes have not changed substantially during the past two decades. Researchers have tended to focus on environmental factors such as the availability of highly palatable and caloriedense fast food to promote high energy intake as well as the appeal of television, video games, and computers to discourage energy expenditure.

Children and adolescents are increasingly engaging in sedentary behavior, spending less time exercising outdoors and more time watching television and playing video games. The Third National Health and Nutrition Examination Survey (1988-1994) indicates that 20 percent of US children aged 8 to 16 participated in 2 or fewer bouts of vigorous activity per week, and more than 26 percent watched at least 4 hours of 
television per day and 67 percent watched at least 2 hours per day (Andersen et al. 1998).

Television viewing may contribute to childhood obesity both by reducing energy expenditure from displacement of physical activity and increasing energy intake from increased snacking during television viewing or as a result of exposure to food advertising.

How the commercial advertising of foods contributes to the epidemic of obesity among children and adolescents is still an ongoing debate. There is widespread speculation that the exposure to food advertising may contribute to unhealthy food choices and weight gain. Despite lacking evidence showing the direct linkage between television food advertising and childhood obesity, several industrialized countries such as Sweden, Norway, and Finland have banned commercial sponsorship of children's programs. Sweden also does not permit any television advertising targeting children under the age of twelve (Kaiser Family Foundation 2004). In the United States, most recently, companies such as Kraft Foods have decided to curb advertising aimed at children in an effort to encourage better eating habits (Mayer 2005). However, the Bush administration has argued that no one has proven that advertising causes obesity and did not take any action in regulating advertising directed at children, after the World Health Organization proposed that countries be urged to limit advertisements that encourage unhealthy diets, especially those directed at children.

The purpose of this paper is to explore the causal relationship between exposure to fast-food restaurant advertising on television and childhood obesity. We employ two individual-level data sets: the National Longitudinal Survey of Youth 1997 for adolescents aged 12 to 18 and the Child-Young Adult National Longitudinal Survey of 
Youth 1979 for children aged 3 to 11. The data for fast-food restaurant advertising on television are appended to the individual-level data by designated market area and year. We employ several different specifications and most results show a positive impact of fast-food restaurant advertising on television on body mass index and the probability of being overweight for children and adolescents, some estimates being statistically significant and others not.

\section{BACKGROUND AND LITERATURE REVIEW}

Obesity is measured by the body mass index (BMI), also termed Quetelet's index, and defined as weight in kilograms divided by height in meters squared. Persons 18 years of age and older with a BMI greater than or equal to $30 \mathrm{~kg} / \mathrm{m}^{2}$ are classified as obese. An overweight child or adolescent (the term obese is reserved for adults) is defined as one having a BMI at or above the 95th percentile based on age- and genderspecific growth charts for children and adolescents in the second and third National Health Examination Surveys (NHES II and NHES III), conducted between 1963 and 1965 and between 1966 and 1970, respectively, and from the first, second, and third National Health and Nutrition Examination Surveys (NHANES I, NHANES II, and NHANES III), conducted between 1971 and 1974, 1976 and 1980, and 1988 and 1994, respectively. ${ }^{1}$

\footnotetext{
${ }^{1}$ Prior to 2000, the growth charts excluded data from NHANES II and III. The 2000 revisions included children and adolescents in NHANES II and children under 6 in NHANES III to make the charts more nationally representative. There is little difference, however, between the two sets of charts, especially for children over the age of 1 (Kuczmarski et al. 2002). In particular, trends are not distorted by the use of examinations in different years to construct the growth charts.
} 
Trends in the mean body mass index of persons ages 3-11 (hereafter termed children) and the percentage overweight between 1963 and 2000 are presented in Table 1a. Similar data for persons aged 12-18 (hereafter termed adolescents or teenagers) are presented in Table 1b. These data come from heights and weights obtained from physical examinations conducted in NHES II and III, in NHANES I, II, and III, and in 1999-2000 NHANES (NHANES 99). ${ }^{2}$ Both tables show dramatic increases in the percentage of overweight children and teenagers between 1978 (the mid-year of NHANES II) and 2000. This percentage doubled for teenagers and almost tripled for children. For teenagers, the relatively flat trend prior to 1978 and the rapid increase since that year mirror the behavior of the trend in obesity for adults (Chou et al. 2004). For children, the picture is somewhat different. There appears to be an upward trend throughout the period, but the figures for 1963-65 pertain to children ages 6-11. As shown by Ogden et al. (2002), if the series on overweight is limited to this age range, there is no increase between 1964 (the mid-year of NHES II) and late 1972 (the mid-point of NHANES I, which began in May 1971 and ended in June 1974). This percentage rises between 1972 and 1978 for 611 year-olds, but it does not rise for 3-5 year-olds. In any case, data from the most recent NHANES survey suggest that the upward trend in the percentage of children and teenagers who are overweight between NHANES II and NHANES III continued through the year 2000 .

Obesity puts children and adolescents at risk for a range of health problems and can affect cardiovascular health (hypercholesterolemia and dyslipidemia, hypertension), the endocrine system (hyperinsulinism, insulin resistance, impaired glucose tolerance,

\footnotetext{
${ }^{2}$ For adolescents in the earliest period, NHES I, conducted between 1959 and 1962, is used for 18-yearolds.
} 
type II diabetes mellitus, menstrual irregularity), and mental health (depression, low selfesteem) (Krebs and Jacobson 2003). For example, the prevalence of type II diabetes in children, originally termed adult-onset diabetes, went from four percent in 1982 to 16 percent in 1994 (Squires 1998). Overweight children and adolescents are likely to grow into overweight adults. The probability of childhood obesity persisting into adulthood is estimated to increase from about 20 percent at 4 years of age to approximately 80 percent by adolescence (Krebs and Jacobson 2003). Some estimates suggest that the increasing prevalence of overweight and obesity accounts for approximately 300,000 deaths every year, next only to the preventable mortality associated with cigarette smoking (McGinnis and Foege 1993; Allison et al. 1999). In a more recent study, Flegal et al. (2005) report a smaller but still substantial figure of approximately 112,000 excess deaths in the year 2000. Aggregate medical spending for the United States that is attributed to obesity accounted for 9.1 percent of total annual medical expenditures in 1998 , as high as $\$ 78.5$ billion (Finkelstein et al. 2003).

Behavioral and environmental factors are large contributors to the obesity epidemic and also the most easily modifiable causes of obesity among children (Hill and Peters 1998; US Department of Health and Human Services 2001). Television viewing is suspected to be one potential contributor to childhood obesity through several possible avenues. ${ }^{3}$ First, television viewing time will displace time spent engaging in physical activity. The sedentary nature of watching television further encourages one to consume unhealthy foods. Moreover, being exposed to food advertisements on television, children and adolescents are more prone to developing unhealthy dietary habits that are likely to carry over into adulthood. Most studies using cross-sectional data have found a

\footnotetext{
${ }^{3}$ See Kaiser Family Foundation (2004) for a more detailed report on the role of media in childhood obesity.
} 
significant correlation between obesity prevalence and television viewing (Dietz and Gortmaker 1985; Gortmaker et al. 1996; Crespo et al. 2001; Andersen et al. 1998), but others have not (Robinson et al. 1993). The results based on a randomized controlled school-based trial aimed at reducing television viewing for school-aged children has provided strong evidence to support the role of limiting television time in the prevention of childhood obesity (Robinson 1999). Two longitudinal studies also found the persistent effect of television viewing on body fat over time (Hancox et al. 2004; Proctor et al. 2003). Hancox et al. (2004) have shown that television viewing during childhood and adolescence is associated with an increased likelihood of being overweight in early adulthood. Proctor et al. (2003) found that preschool children who watched the most television had the greatest possibility of becoming overweight adolescents.

In the period during which childhood obesity increased so drastically, there was also an increased amount of time spent watching television and an increased exposure to food advertising by children and adolescents. Around 1950, only two percent of households in the United States had television sets; by the early 1990s, 98 percent of households owned at least one, and over 60 percent had cable television (Huston 1992; Donnerstein et al. 1994). In the late 1970s, children viewed an average of about 20,000 commercials aired on television per year. The number increased to 30,000 per year in the late 1980s and more than 40,000 per year in the late 1990s (Kunkel 2001). Moreover, the majority of advertisements targeted at children are ones of food with minimum nutritional value: candy (32 percent of all children's ads), cereal (31 percent), and fast-food restaurants (9 percent) (Kunkel 2001). In 1997 US food manufacturers spent \$7 billion 
on product advertising. Money spent on fast-food restaurant advertising made up about 28 percent of advertising, up from only five percent in 1980 (Gallo 1999).

While most prior studies have confirmed correlations between television watching and obesity in children, few studies have looked at the effect that fast-food restaurant advertising on television per se might have on childhood obesity. Several studies reviewed by the Kaiser Family Foundation (2004) indirectly pointed to the positive relationship between television advertising and caloric intake. For example, Giammattei et al. (2003) found that middle-school children who watched more television tended to consume more soft drinks, a possible consequence of exposure to food advertising on television. Borzekowski and Robinson (2001) have shown that even brief exposures to televised food commercials can influence preschool children's food preferences. Based on a randomized trial, children exposed to videotapes with embedded commercials were significantly more likely to choose the advertised items. However, two cross-sectional studies cited in Ashton (2004) supported the argument that there was no causal relationship between television advertising and childhood obesity. One study showed that childhood obesity rates were no different in Quebec, where food advertising aimed at children has been banned since 1980, from those rates in other Canadian provinces. The other showed that Sweden, where a similar advertising ban has existed for over a decade, did not have lower childhood obesity rates.

Among many potentially important contributors to a positive energy balance, fastfood restaurant advertising on television is the main focus of this study. Children are easily molded by what they see in television commercials. Studies indicate that the more children watch television, the more they specifically request the brand-name products that 
are advertised on television when at the grocery store. ${ }^{4}$ Consumer behavior in response to advertising could be explained using Becker and Murphy (1993), where a model in which a brand's advertising level interacts with consumption in the consumer's utility function is proposed. In this model, by treating advertising as a complementary good, consumers may simply derive more utility from consuming a more advertised good. As an example, it may be that a child values the toys that go together with the commercial products, and advertising may then serve as an input that enables the consumer to derive more utility when the advertised product is consumed. Moreover, children - especially younger ones - may not be able to distinguish advertisements from regular programs and have little understanding of their persuasive intent. Using children's favorite characters and linking products with concepts such as fun, happiness, and well-being, food advertisements can successfully entice children to consume their products.

Nevertheless, the effect of television advertising on childhood obesity is complex, dealing with the interplay between the characteristics of the children, the attitudes of their parents, and environmental settings. Our empirical study attempts to isolate the effect of fast-food restaurant advertising on television on obesity in children and adolescents.

\section{DATA AND SAMPLE}

The micro-level data set that we use for adolescents aged 12 to 18 is the National Longitudinal Survey of Youth 1997. The National Longitudinal Survey of Youth 1997 (hereafter NLSY97) is a nationally representative sample of the US population aged 12 to 16 years old as of December 31, 1996. The initial sample in 1997 consists of 8,984

\footnotetext{
${ }^{4}$ See Kaiser Family Foundation (2004) for a reference.
} 
respondents originated from 6,819 unique households. Two subsamples comprise the NLSY97 cohort. The first is a nationally-representative sample of 6,748 respondents born between 1980 and 1984. The second consists of 2,236 oversampled black and Hispanic respondents for that age group. The survey has collected extensive information about youth labor market behavior and educational experiences over time. Round 1 of the NLSY97, which took place in 1997, contains a parent questionnaire that generates information about the youth's family background and history. Only 7,942 youth respondents, out of 8,984 , have information available from a parent interview. The NLSY97 also contains information on time use including the amount of time spent in the prior week watching television from youth aged 12 to 14 in Round $1 .^{5}$

We pool 3 rounds of NLSY97 for the analysis: $1997(\mathrm{~N}=8,984), 1998(\mathrm{~N}=8,386)$ and $1999(\mathrm{~N}=8,209) .{ }^{6}$ Before any state-level or advertising data are appended to the NLSY97, the pooled sample size is 14,852 when observations with missing values are deleted. Note that a large percentage of observations are dropped due to the missing values on television watching time. This question is not asked of youth over the age of 14 in 1997 (Round 1), and it is not asked after that year. Therefore, we assume that the 1997 values also apply to 1998 and 1999.

We also use the matched mother-child data from the National Longitudinal Survey of Youth 1979 (hereafter NLSY79) for children aged 3 to 11. The NLSY79 is a nationally representative sample of 12,686 individuals, of whom 6,283 were women who were 14-22 years old when they were first surveyed in 1979. In 1986, biennial interviews of all children born to female respondents began, making up the Child and Young Adult

\footnotetext{
${ }^{5}$ Out of 8,984 , only 5,419 youth respondents were between the ages of 12 and 14 in Round 1 . Thus, $40 \%$ of our sample was dropped due to the missing values on television watching time.

${ }^{6}$ We do not use the year 2000 for NLSY97 because our advertising data are from 1996 to 1999.
} 
File. We use three survey years of data, 1996, 1998, and 2000. The television watching variable is available in each of these years. We restrict both final samples to those individuals that have a body mass index not less than $11 \mathrm{~kg} / \mathrm{m}^{2}$ and not greater than $140 \mathrm{~kg} / \mathrm{m}^{2}$.

Fast-food restaurant television advertising data are obtained from Competitive Media Reporting (CMR), the largest provider of advertising tracking services in the United States. This has exposure information and dollar expenditures for a wide array of fast-food restaurant chains in the United States from 1996 to 1999. ${ }^{7}$ Competitive Media Reporting was formed in 1992 by combining several advertising tracking and broadcast proof-of-performance companies. The exposure variable equals the annual number of seconds of fast-food restaurant messages aired on television. This variable is then divided by a factor of $(60 * 60 * 52)$ or 187,200 to convert it into the weekly number of hours of fast-food restaurant advertising messages aired. The unit of observation for this variable is the DMA, or Designated Market Area, which is similar to a Metropolitan Statistical Area. The designated market area is a region composed of counties (and occasionally split counties) that defines a television market. Thus, the advertising data were appended to our individual records by DMA and year. ${ }^{8}$ Out of about 210 DMAs, the top 75 (in terms of TV households) are contained in the CMR database and used in

\footnotetext{
${ }^{7}$ The corporations we chose for this analysis that we believed best reflected the fast-food industry were: A\&W Restaurants Inc, AFC Enterprises, Allied Domecq Plc, Arthur Treachers Inc, Carrols Corp, Chester Fried Chicken Restaurants, Chick-Fil-A Inc, Cici Enterprises Inc, Cke Restaurants Inc, Culver Franchising System Inc, Diageo Plc, Dominos Pizza Inc, Fatboys Franchise Systems Inc, Foodmaker Inc, Galardi Group, Hungry Howies Pizza \& Subs Inc, Ich Corp, In-N-Out Burgers Inc, Inno-Pacific Holdings Inc, Krispy Kreme Doughnut Corp, Krystal Co, Leeann Chin, Little Caesars Enterprises Inc, Long John Silvers Inc, McDonalds Corp, Panda Express, Papa Ginos Inc, Papa Johns Intl Inc, Quality Dining Inc, Ranch 1, Rax Restaurants Inc, Showbiz Pizza Time Inc, Sizzler Intl Inc, Sonic Corp, Speedy Burgers Inc, TCBY Enterprises Inc, Triarc Cos Inc, Tricon Global Restaurants Inc, Wendys Intl Inc, Whataburger Inc, and White Castle System Inc.

${ }^{8}$ We append 1999 advertising data to 2000 NLSY79 data by DMA.
} 
our study. As a consequence, our final sample sizes, when the advertising data are appended, are 6,322 person-years for respondents aged 3 to 11 (NLSY79) and 6,818 person-years for respondents aged 12-18 (NLSY97).

Note that network television, syndicated television, and cable network television advertising are not included in our data because they have no local variation. National advertising effects cannot be obtained in the specifications that we employ since they contain dichotomous year indicators. Spot television advertising has local variation and is reported by year and by market area by CMR. That is the type of advertising that we consider.

An important conceptual issue that arises in measuring the impact of exposure to advertising on consumer behavior is whether the effect on any one consumer depends on the total number of minutes of advertising aired on television in the consumer's DMA or on the per capita number of minutes aired. This depends on whether advertising is treated as a public good. Public goods are non-excludable and non-rejectable. If street signs are public goods, then a billboard showing an ad, for example, can be viewed as a public good (or a public "bad" if over-provided). This is not as straightforward with advertisements on television, which could be excludable (unless everyone owns a television set) or rejectable (as one can turn the channel if one chooses to do so).

The advertising literature seems to be mixed with regard to using total exposure or this variable per capita. ${ }^{9}$ The most compelling justification for total exposure is that two consumers cannot eat the same apple, but two consumers can watch the same advertisement. The most compelling justification for the per capita specification is that

\footnotetext{
${ }^{9}$ For example, Saffer (1997), Tellis and Weisee (1995), and Tellis et al. (2000) use advertising only, while Saffer and Dave (2003) use exposure per capita.
} 
there are more television stations in larger market areas. This lowers the probability that two consumers will see the same advertisement in a larger market even if they spend the same amount of time watching television. Because the first factor seems to us to be more important than the second (two consumers in the same market area certainly can view the same advertisement no matter how large the area), we emphasize results with total exposure. In preliminary research, we found that results for per capita exposure were similar to those with total exposure.

As will be described in more detail in Section IV, we will employ a two-stage least squares estimation to correct for the potential endogeneity of the advertising variable. The price variable, which is used as an instrument in our study, is created by dividing dollar expenditures by exposure time (messages aired) within a designated market area. CMR is also the source for the number of households in a DMA with a television set, also used as an instrument for the exposure variable. Annual temperature, our third instrument, pertains to the mean 1976 temperature in the county of residence, and is obtained from the 1998 Area Resource File.

To control for other factors that might affect caloric intake and caloric expenditure, we also include several state-level variables that are appended to the individual data by state and year. The number of fast-food restaurants and the number of full-service restaurants are taken from the Census of Retail Trade. Three food prices are also included: full-service restaurant price, fast-food restaurant price, and food at home price. The first price variable is taken from the same source as the number of restaurants, namely the Census of Retail Trade. The last two price variables are obtained from the American Chamber of Commerce Researchers Association (ACCRA). The price of 
cigarettes is taken from the Tax Burden on Tobacco (Orzechowski and Walker 2002). Clean indoor air laws are taken from the Centers for Disease Control and Prevention website (http://www2.cdc.gov/nccdph/osh/state). More detailed descriptions of the definitions and construction of these variables and their roles in equations for weight outcomes can be found in Chou et al. (2004).

\section{EMPIRICAL IMPLEMENTATION}

We employ parental reports of height and weight in NLSY79 and adolescent reports of height and weight in NLSY97 to construct two dependent variables: body mass index (BMI) and an indicator that equals one if the child or adolescent is overweight. Given the large sample size, we fit linear probability models rather than logit or probit models when the overweight indicator is the outcome. Our most inclusive regression model is

$$
Y_{i j t}=\alpha+\gamma_{1} S_{i j t}+\gamma_{2} T_{i j t}+\beta_{o} X_{i j t}+\beta_{1} M_{i j t}+\beta_{2} Z_{i j t}+\mu_{j}+v_{t}+\varepsilon_{i j t} .
$$

In this equation, the dependent variable $\left(Y_{i j t}\right)$ is the weight outcome (BMI or overweight) for person $i$ in DMA $j$ surveyed in year $t$. The regressors are the number of hours of spot television fast-food restaurant advertising messages seen per week $\left(S_{i j t}\right)$; the number of hours per week spent watching television $\left(T_{i j t}\right)$; a vector of demographic variables for children or adolescents, including age, race, and gender $\left(X_{i j t}\right)$; a vector of variables containing mother's employment status, household income, a dummy for missing income, and dummy variables indicating whether the mother is overweight (BMI of $25 \mathrm{~kg} / \mathrm{m}^{2}$ or greater) or obese $\left(M_{i j t}\right)$; a vector of state-specific variables including the per capita 
number of fast-food restaurants, the per capita number of full-service restaurants, the real cigarette price, dichotomous indicators for clean indoor air laws, the real full-service restaurant price, the real food at home price, and the real fast-food restaurant price $\left(Z_{i j t}\right)$; and vectors indicating DMA $\left(\mu_{j}\right)$ and year $\left(v_{t}\right)$. The disturbance term is $\varepsilon_{i j t}$.

Whether the mother is overweight or obese helps to partially capture the genetic component that determines a child's body mass index. The effect of food advertising on children and adolescents also depends on the resources allocated by parents for food consumption by the family, to parental response to their children's food purchase requests, and to parental control of their food consumption. We include family income and mother's employment status to control for parental influence on children's and adolescents' food consumption. ${ }^{10}$ Anderson et al. (2003) focus on children and find that maternal employment has an effect on obesity in children.

Our main variable of interest is the number of hours of spot television fast-food restaurant advertising messages seen per week $\left(\mathrm{S}_{\mathrm{ijt}}\right)$. We compute this as

$$
\mathrm{S}_{\mathrm{ijt}}=\mathrm{p}_{\mathrm{ijt}} \mathrm{A}_{\mathrm{jt}}
$$

where $A_{j t}$ is the number of hours of messages aired per week and $p_{i j t}$ is the probability that a given child or adolescent saw one hour of advertising. In turn, this probability is estimated as

$$
\mathrm{p}_{\mathrm{ijt}}=\mathrm{T}_{\mathrm{ijt}} / 168
$$

where $T_{i j t}$ is the number of hours per week that the child or adolescent watches television and 168 equals the total number of hours in a week. This assumes that the ratio of hours

\footnotetext{
${ }^{10} \mathrm{We}$ do not account for the potential endogeneity of mother's employment status in our regressions, as that is not the main focus of this paper. See Anderson et al. (2003) for an analysis of the impact of mother's employment status on childhood obesity while accounting for potential endogeneity.
} 
of advertising seen to hours of advertising aired is equal to the ratio of hours of television seen to hours available for all activities including sleep.

An advantage of the specification given by equation (1) is that it allows the amount of time spent watching television to have an effect on weight outcomes that is independent of the number of minutes of fast-food restaurant advertising messages seen. One disadvantage is that $\mathrm{T}_{\mathrm{ijt}}$ and $\mathrm{S}_{\mathrm{ijt}}$ are highly correlated, which makes it difficult to sort out the partial impact of each factor. A second disadvantage is that the relationship between watching television and weight reflects causality in both directions: more overweight children tend to be more sedentary and thus watch more television. To circumvent the first problem, we fit a second model that omits $\mathrm{T}_{\mathrm{ijt}}$ as a regressor. To circumvent the second, we estimate a third model in which advertising exposure is given by $\mathrm{A}_{\mathrm{jt}}$, the number of hours of messages aired. ${ }^{11}$

By including DMA or area effects, we control for time-invariant unmeasured factors that are correlated with television advertising and weight outcomes. For example, fast-food restaurants may choose to place more advertisements in areas where residents have a higher than average taste for caloric foods, and hence a larger percentage of the population is overweight. Since the children of overweight parents are more likely to be overweight than the children of normal-weight parents, advertising effects are biased if area effects are omitted.

Although an individual fixed effects model controls for DMA fixed effects if individuals do not move, we estimate a DMA fixed effects model for several reasons. First, the amount of time spent watching television in the NLSY97 is available only in the

\footnotetext{
${ }^{11}$ It should be noted that children or adolescents who do not watch any television are also assumed to be exposed to fast-food advertising in this specification, possibly through interactions with peers.
} 
first year of the panel and cannot be used as a regressor with individual fixed effects.

Second, the key unobservables governing area-level advertising decisions are characteristics pertaining to the population of the area. Since an individual picked at random in an area with a strong taste for dining in fast-food restaurants is likely to share the tastes of the area, the area indicator reflects that factor.

The last factor is important because the area fixed effects model is more efficient than the individual fixed effects model. This is true because the former model involves the estimation of far fewer parameters. Indeed, preliminary results revealed similar point estimates of advertising coefficients but larger standard errors in individual fixed effects models compared to area fixed effects models. ${ }^{12}$ We do account for the panel nature of the data and for the measurement of at least one component of the advertising variable at the area level by clustering by DMAs in obtaining standard errors of regression coefficients. This allows the disturbance term $\left(\varepsilon_{\mathrm{ijt}}\right)$ to be correlated for the same person over time and to be correlated among different persons in the same DMA both at a moment in time and over time.

If advertising is determined simultaneously with consumption in fast-food restaurants, then the advertising variable in each of our models is correlated with the disturbance term or at least with its component that varies within areas over time $\left(\varepsilon_{\mathrm{jt}}\right)$. Put differently, the advertising coefficient is inconsistent if it is obtained by ordinary least squares (OLS) because the amount of advertising in an area is positively related to consumption in fast-food restaurants and hence to the mean BMI or the percentage of the population that is overweight in the area. To deal with this problem, we estimate two of

\footnotetext{
${ }^{12}$ This comparison could only be done for NLSY79 because we could not estimate individual fixed effects models for NLSY97, as explained above.
} 
our three specifications by two-stage least squares (TSLS) with the relevant advertising measure $\left(\mathrm{S}_{\mathrm{ijt}}\right.$ or $\left.\mathrm{A}_{\mathrm{jt}}\right)$ treated as an endogenous variable. We use the price of advertising, the number of households in the DMA with a television set, and the average annual temperature in the respondent's county of residence as instruments.

We do not estimate the specification that includes both the amount of time spent watching television $\left(\mathrm{T}_{\mathrm{ijt}}\right)$ and messages seen $\left(\mathrm{S}_{\mathrm{ijt}}\right)$ in our TSLS models because the former variable is likely to be endogenous, and we lack instruments to predict both. Note that the model that omits $T_{\mathrm{ijt}}$ but includes $S_{\mathrm{ijt}}$ can be viewed as a quasi-structural equation in the sense that $T_{i j t}$ has been replaced by its determinants, all of which enter the pure structural equation. Similarly, the model that omits $S_{\mathrm{ijt}}$ but includes $\mathrm{A}_{\mathrm{ijt}}$ can be viewed as a quasi-reduced form because $S_{\mathrm{ijt}}$ is replaced by its key determinant, which is omitted from the quasi-structural equation. We estimate the quasi-structural equation and the quasi-reduced form equation by TSLS as well as by OLS.

Means and standard deviations for the NLSY79 and NLSY97 data sets are reported in Tables $2 \mathrm{a}$ and $2 \mathrm{~b}$. These means and the regressions in the next section employ the NLSY sampling weights. In NLSY79, heights and weights are obtained from measurements taken by interviewers for approximately 75 percent of the sample. The remainder of the height and weight data are reported by mothers. All of our regression models for this sample include a dichotomous indicator that equals one if BMI and overweight are based on mother reports since they are more likely to result in errors in BMI and in the classification of overweight status. In NLSY97, heights and weights are reported by adolescents. 
The average BMIs are $17.60 \mathrm{~kg} / \mathrm{m}^{2}$ and $22.11 \mathrm{~kg} / \mathrm{m}^{2}$ for children aged $3-11$ and adolescents aged 12-18, respectively. Moreover, 15.6 percent of the children (NLSY79) and 10.4 percent of the adolescents (NLSY97) are overweight. All of these figures except for the last one are comparable to those from NHANES99 in Tables 1a and 1b. To be specific, adolescents are 40 percent more likely to be overweight in NHANES99 than in NLS97. Almost all of this difference results because adolescent girls are twice as likely to be overweight in NHANES99 than in NLSY97. Undoubtedly, this reflects a reluctance by adolescent girls to report their true weight.

Inclusion of a gender indicator in NLSY97 regressions controls for the source of response error just described. Of course, one cannot decompose the gross difference in overweight status between adolescent males and females or the difference net of other regressors into a component due to response error and a component due to other factors. But as long as response error is uncorrelated with variables other than gender, regression coefficients of these variables are unbiased, although their standard errors are inflated. Hence, the t-ratios on which tests of significance are based are conservative lower-bound estimates.

If reporting errors result in a constant percentage reduction in BMI, all slope coefficients involving this outcome, including those associated with fast-food advertising, are understated. When the probability of being overweight is the outcome, the bias is less obvious even if, as we hypothesize, overweight girls are more likely to be found in areas with relatively large amounts of fast-food advertising on television. That depends on the distribution of girls around the overweight cutoff among areas and the degree to which response error in percentage terms is correlated with true weight. If too few girls 
are classified as overweight in areas with relatively large amounts of advertising, the associated coefficients are conservative lower-bound estimates. Note that all percentage changes in BMI and in the number of overweight children and adolescents computed from regression results in Sections V and VI employ NHANES99 means. If slope coefficients are unbiased, this corrects for the upward bias in the absolute value of the impact of a change advertising on the percentage change in the number of overweight adolescents that would result if NLSY97 means were employed in the computations.

\section{RESULTS}

Table 3 presents results where the body mass index is the dependent variable for children aged 3-11 (upper panel) and for adolescents aged 12-18 (lower panel). Regressions are also run separately by gender because the results of Chow tests (not shown) indicate significant differences between male and female slope coefficients in most specifications. ${ }^{13}$ Pooled regressions are presented for completeness, for the interest of the reader, because they are based on more observations than the gender-specific regressions, and because of the response errors associated with weight outcomes of adolescent girls discussed in the previous section. Moreover, the policy initiatives that we consider at the end of this section are not gender-specific. In almost all cases, the advertising coefficient in a given regression is a simple average of the corresponding gender-specific coefficients. Hence, the pooled coefficient can be used to evaluate the impact of the policy at issue.

\footnotetext{
${ }^{13}$ These tests allow the intercept to vary by gender.
} 
In all specifications, individual characteristics, as well as DMA and year fixed effects, are included. In specification 1, we include both television watching time $(T)$ and fast-food restaurant advertising messages seen on television $(S)$ as explanatory variables. We find a positive and significant relationship between advertising and children's body mass index. ${ }^{14}$ Moreover, advertising has a larger and more significant impact on boys than on girls. Yet TV watching time does not have a significant impact on children's body mass index, regardless of gender. Results suggest that increasing exposure to fastfood advertising by a half hour per week (an approximate one standard deviation increase) will increase a boy's BMI and a girl's BMI by $0.30 \mathrm{~kg} / \mathrm{m}^{2}$ (or 2 percent) and $0.12 \mathrm{~kg} / \mathrm{m}^{2}$ (or 1 percent), respectively. ${ }^{15}$ On the contrary, the messages seen variable is insignificant for adolescents but television watching time is shown to have a positive and significant effect on body mass index for adolescents.

Since television watching time and advertising messages seen are highly correlated, we only include the messages seen in the second specification to sort out the impact of advertising. Results show that the number of hours of messages seen on television has a strong positive effect on BMI for both children and adolescents. Messages seen have similar effects on BMI for boys and girls aged 3-11 but have a larger impact on teenage boys. Results also suggest that fast-food restaurant advertising has a larger impact on adolescents than on children, despite the latter group's longer exposure to fast-food restaurant advertising due to longer television viewing time. Several possibilities could be attributed to this finding. Adolescents have larger influences on family purchasing decisions than children and also purchase more fast food with their

\footnotetext{
${ }^{14}$ We evaluate the significance of advertising coefficients with one-tailed tests since the alternative hypothesis is that these coefficients are positive.

${ }^{15}$ We use the means from the NHANES 99 data set to calculate the percentage change.
} 
own money than younger consumers. ${ }^{16}$ Adolescents make up a large portion of the labor force at fast-food restaurants, where they may receive discounted or free food as part of their compensation. Moreover, preponderant fast-food restaurant advertising may have an everlasting and progressive influence because of the cumulative effects of repetitious messages. Bowman et al. (2004) confirm the positive association of fast food restaurant consumption with age. Our results suggest that increasing fast-food restaurant advertising messages seen by a half hour per week will increase both a boy's BMI and a girl's BMI by $0.16 \mathrm{~kg} / \mathrm{m}^{2}$ (or roughly 1 percent). The same increase of exposure to fast food restaurant advertising will increase a teenage boy's BMI and a teenage girl's BMI by $0.49 \mathrm{~kg} / \mathrm{m}^{2}$ (or 2 percent) and $0.37 \mathrm{~kg} / \mathrm{m}^{2}$ (or 2 percent), respectively.

We do not find a significant impact of messages seen on overweight status for either children or adolescents when television watching time is included in the regressions (Table 4, specification 1), although we wish to emphasize again that television watching time is highly correlated with messages seen. When television time is excluded (specification 2), advertising messages seen significantly increases a child's probability of being overweight. The effect for boys is somewhat larger than that for girls (upper panel of Table 4). Advertising has a larger impact on the probability of being overweight for adolescents, but the messages seen coefficient shows statistical significance only for all teenagers and teenage males (lower panel of Table 4). Our results indicate that increasing fast-food restaurant advertising messages seen by a half hour per week will increase the probability of being overweight by 1.6 percentage points (11 percent) and 1.1 percentage points (8 percent) for boys and girls aged 3-11,

\footnotetext{
${ }^{16}$ See Nestle (2002), p.178. Those aged 10-12 and aged 7-9 spend 25 percent and 16 percent of their own money on fast food, respectively.
} 
respectively. An equivalent increase in fast-food restaurant advertising messages seen for teenage males and females will increase their probabilities of being overweight by 3.2 percentage points (21 percent) and 0.6 percentage points ( 4 percent $)$, respectively. The larger effects for males relative to females, especially in the adolescent sample, may reflect a greater concern by females about their weight. They may also reflect in part underreporting of weight by adolescent females.

To account for the possible endogeneity of the advertising exposure variable, we fit instrumental variables models in which the price of advertising (measured in dollars per seconds of messages aired), the number of households with a television in the DMA, and average annual temperature serve as instruments for advertising. ${ }^{17}$ In conducting the instrumental variable regressions, we employed specification 2 where the endogenous variable is exposure to fast-food restaurant advertising (messages seen). Personal characteristics, DMA and year fixed effects, and state variables are all included in the model. Partial first stage results are shown in Panel $\mathrm{C}$ of Table 5. The price of an advertisement significantly reduces fast-food restaurant advertising exposure on television. The number of households with television sets has a significantly positive effect on exposure in the regressions for adolescents.

The IV test results reported in Panels A and B of Table 5 suggest that the messages seen variable is not endogenous - all the Durbin-Wu-Hausman tests are not rejected, regardless of the sample. To verify the validity of our instruments, we also conduct overidentification tests (Hansen's J statistics) and F tests of the significance of

\footnotetext{
${ }^{17}$ The use of lagged values for the advertising variable in an attempt to get around the possible endogeneity problem is not an attractive strategy, as it has been shown that advertising effects depreciate rapidly (Boyd and Seldon 1990). The shape of the response function is believed to be concave-downward, so that exposure to a given advertising message has diminishing effects, or conveys less and less information with each additional exposure (Simon and Arndt 1980).
} 
the set of instruments in the first stage. None of the Hansen's J statistics is rejected at the 5 percent level. This implies that the null hypothesis - that the instruments are uncorrelated with the error terms - is confirmed. The F statistics range between 19 and 51, suggesting that the IV estimates are not biased because the instruments are weakly correlated with the endogenous explanatory variables (Bound et al. 1995; Staiger and Stock 1997). Given the test results, we do not further report the IV results on advertising in this specification.

To further explore the endogeneity of advertising and television viewing and the problems caused by measurement error in the viewing variable, we estimate a model in which advertising exposure is measured by the number of hours of messages aired in the respondent's DMA in Table 6. The results of overidentification tests and F tests of the significance of the instruments in the first stage are similar to those in Table 5. DurbinWu-Hausman tests are not rejected, suggesting that the exposure variable is not endogenous. Hence, only OLS advertising coefficients are shown in Table 6.

For children aged 3-11, the exposure variable has a positive effect on the body mass index and the probability of being overweight, but results are not statistically significant. The advertising exposure variables are positive in all regressions for adolescents and have larger and more significant impacts in male regressions. These results suggest that increasing the messages aired in a respondent's DMA by an hour (approximately a one standard deviation increase) will increase a child's BMI by 0.04 $\mathrm{kg} / \mathrm{m}^{2}(0.2$ percent $)$ and the probability of being overweight by 0.6 percentage points ( 4 percent). It will also increase teenage BMI by $0.09 \mathrm{~kg} / \mathrm{m}^{2}(0.4$ percent) and the probability of being overweight by 0.6 percentage points ( 4 percent). 
Finally, regression results for other explanatory variables are reported in Table A1 (for children aged 3-11) and Table A2 (for adolescents aged 12-18) in the Appendix. For children aged 3-11 (Table A1), BMI increases with age, but the probability of being overweight is negatively associated with age. Hispanic boys and black girls are associated with higher body mass indexes and higher probabilities of being overweight. Boys are also more likely to be overweight. Higher family income significantly reduces a child's body mass index and the probability of being overweight, regardless of gender. A wealthy family is more capable of choosing a healthy diet by staying away from calorie-rich but relatively cheap fast food. Yet they are also more able to consume at "upscale" restaurants where food is rich in calories as well. Our results suggest that the first factor dominates the second one. Mother's weight status is a strong predictor of a child's body mass index and the probability of being overweight, revealing a powerful genetic component. Mother's employment status has no impact on these outcomes.

For adolescents aged 12-18 (Table A2), being a black teenage female is strongly associated with having a higher body mass index and a higher probability of being overweight. Family income is associated with a lower body mass index and the probability of being overweight. Again, a mother's overweight or obese status is strongly associated with the body mass index and the probability of being overweight, but a mother's employment status is not significantly associated with these outcomes.

Most state variables are not statistically significant in the regressions. We summarize some interesting findings with regard to those state variables. First, a higher cigarette price leads to a higher probability of being overweight for teenage females (Table A2, the last column). This finding is consistent with several streams of literature: 
The price elasticity of cigarettes for youth is large and smoking cessation usually results in weight gain. Moreover, teenage girls are more sensitive to their body weight and are more likely to control weight by smoking (Cawley et al. 2004). Second, higher fast-food prices will lead to lower body mass indexes for adolescents. Fast food is rich in calories and its consumption may further adversely affect diet quality such as by reducing daily servings of fruit and vegetables (Bowman et al. 2004; French et al. 2000). Higher fastfood prices may reduce its consumption and decrease the body mass index. Third, the number of fast-food restaurants is positively associated with a child's BMI and the probability of being overweight.

\section{DISCUSSION}

The investigation of the causal relationship between fast-food restaurant advertising and body weight among children and adolescents is important when forming policies to cope with the obesity epidemic. Overall, our results show a strong positive effect of exposure to fast-food restaurant advertising on the body mass index for children. The effect on the probability of being overweight is less significant. It only shows statistically significant results for the probability of being overweight when we do not allow the television watching time to have an effect that is independent of advertising. We also obtain mixed results for adolescents. When we include both the amount of time spent watching television and the number of advertising messages seen, advertising does not appear to have an effect. The former variable is available only in the first year of the adolescent panel and hence measured with error. When we exclude it, we conclude that 
advertising on television is associated with an increased likelihood that adolescents are overweight. This conclusion is not altered when we treat advertising as endogenous.

Our results could be used to estimate the impact of a fast-food restaurant advertising ban on television on childhood obesity. A complete advertising ban on television would reduce the number of overweight children aged 3-11 in a fixed population by 10 percent. ${ }^{18}$ The decline for boys is approximately 3 percentage points larger than that for girls. The impact of this policy for adolescents aged 12-18 amounts to a slightly larger decline of 12 percent. Here the effect is much more pronounced for males than for females; the difference is approximately 15 percentage points.

These computations underestimate the impact of a complete advertising ban on television because they are based on local or spot television advertising and ignore advertising associated with network, syndicated, and cable television advertising because they have local variation. On the other hand, our results could overestimate the impact of an advertising ban because we ignore advertising in other media (i.e. radio, magazines, outdoor, newspaper). If advertising were equally effective in all media and total advertising remained the same, there would be no impact. If advertising in other media were less effective, especially since we are dealing with youth, and/or the increase was less than the reduction in television advertising, the number of overweight children would fall but by less than our estimates predict. If advertising in all media were banned, the media substitution would be eliminated, and our estimate would be a lower bound. However, such a ban might be difficult to legislate and would not exclude other types of

\footnotetext{
${ }^{18}$ Calculations use specification 2 in Table 4 and means for the percentage overweight from NHANES 99. The number of advertising messages seen is assumed to fall from its age- and gender-specific mean to zero.
} 
marketing, such as sports and cultural events sponsorships, consumer novelties, and the internet.

Another policy option is to eliminate food advertising as ordinary business expenses that reduce taxable corporate income. Since the corporate income tax rate is 35 percent, elimination of the tax deductibility of food advertising costs is equivalent to increasing the price of advertising by about 54 percent. Based on our results, the elimination of tax deductibility of food advertising would reduce fast-food restaurant messages seen on television by 48 percent and 25 percent for children and adolescents, respectively. As a result, elimination of tax deductibility would reduce the number of overweight children and adolescents by 5 percent and 3 percent, respectively. ${ }^{19}$

Clearly, we have not provided enough information to fully evaluate the two policies just discussed. Indeed, we have not addressed the larger issue of whether the government should intervene in the food purchase decisions of its citizens. Obesity carries a high personal cost. But does it carry a high enough social cost to make it a concern of public policy? The answer is no if consumers are fully informed, and if the obese bear all the consequences of their actions. The answer is yes if consumers do not have full information or something that reasonably approximates it, or if third parties like Medicare, Medicaid, private health insurance companies, and ultimately the non-obese end up bearing significant amounts of the costs.

\footnotetext{
${ }^{19}$ These computations employ specification 2 in Table 4 and the reduced-form advertising price coefficients for each age group in Table 5. To be specific, let $\alpha$ be the coefficient of messages seen in the overweight regression, let $\beta$ be the coefficient of price in the messages seen regression, let $p$ be the mean price of a message seen, and let $t$ be the corporate tax rate. Then the reduction in the percentage overweight due to the elimination of the tax deductibility of advertising is $100 \alpha \beta \mathrm{pt} /(1-\mathrm{t})$. Although $\alpha$ is bigger for teenagers than for children, $\beta$ is larger in absolute value for the latter group by an amount sufficient to make the reduction in the percentage overweight slightly larger for children.
} 
In the case of children, one justification for government intervention is that society as a whole may reap substantial current and future production and consumption benefits from improvements in children's health. The deep government involvement in children's lives reflects these potential benefits. Through its sponsorship of school programs, school lunches, and recreational facilities, the government can more easily and immediately affect the choices of children than adults. The case is strengthened because overweight children are extremely likely to become obese adults and because children are less likely to have information about the consequences of their actions or to heavily discount these consequences.

Of course, one would still need to consider the degree of government involvement that is merited and the costs of alternative policies. Relative to positive efforts such as subsidies to programs that encourage children to exercise, advertising bans or increases in the price of advertising impose welfare costs on children and adults who consume fast food in moderation. Additional welfare costs arise because consumers are denied positive information conveyed by advertising. Not surprisingly, an advertising ban not accompanied by media substitution produces larger reductions in the number of overweight children and adolescents than the elimination of the tax deductibility of advertising. But the welfare costs of the former policy are likely to be much larger than those of the latter. Moreover, implementation of both policies raises the difficult issue of distinguishing between fast-food and full-service restaurants and between fast food and other types of food. Hence, more research is required to evaluate the effectiveness of these policies and others. Our study should be viewed as one of many inputs in this process. 


\section{REFERENCES}

Allison DB, Fontaine KR, Manson JE, Stevens J, VanItallie TB. 1999. Annual Deaths Attributable to Obesity in the United States. Journal of the American Medical Association 282: 1530-8.

Andersen RE, Crespo CJ, Bartlett SJ, Cheskin LJ, Pratt M. 1998. Relationship of Physical Activity and Television Watching with Body Weight and Level of Fatness Among Children: Results from the Third National Health and Nutrition Examination Survey. Journal of the American Medical Association 279: 938-42.

Anderson PM, Butcher KF, Levine PB. 2003. Maternal Employment and Overweight Children. Journal of Health Economics 22: 477-504.

Ashton D. 2004. Food Advertising and Childhood Obesity. Journal of the Royal Society of Medicine 97: 51-2.

Becker GS, Murphy KM. 1993. A Simple Theory of Advertising as a Good or Bad. Quarterly Journal of Economics 108: 941-64.

Borzekowski DL, Robinson TN. 2001. The 30-Second Effect: An Experiment Revealing the Impact of Television Commercials on Food Preferences of Preschoolers. Journal of the American Dietetic Association 101: 42-6.

Bound J, Jaeger DA, Baker RM. 1995. Problems with Instrumental Variables Estimation when the Correlation between the Instruments and the Endogenous Explanatory Variable Is Weak. Journal of the American Statistical Association 90: 443-50.

Bowman SA, Gortmaker SL, Ebbeling CB, Pereira MA, Ludwig DS. 2004. Effects of Fast-Food Consumption on Energy Intake and Diet Quality Among Children in a National Household Survey. Pediatrics 113: 112-8.

Boyd R, Seldon BJ. 1990. The Fleeting Effect of Advertising: Empirical Evidence from a Case Study. Economics Letters 34: 375-79.

Cawley J, Markowitz S, Tauras J. 2004. Lighting Up and Slimming Down: the Effects of Body Weight ad Cigarette Prices on Adolescent Smoking Initiation. Journal of Health Economics 23: 293-311.

Centers for Disease Control and Prevention. 2001. Overweight Among US Children and Adolescents. National Center for Health Statistics.

Chou S-Y, Grossman M, Saffer H. 2004. An Economic Analysis of Adult Obesity: Results from the Behavioral Risk Factor Surveillance System. Journal of Health Economics 23: 565-87. 
Crespo CJ, Smit E, Troiano RP, Bartlett SJ, Macera CA, Andersen RE. 2001. Television Watching, Energy Intake, and Obesity in US Children: Results from the Third National Health and Nutrition Examination Survey, 1988-1994. Archives of Pediatrics \& Adolescent Medicine 155: 360-5.

Dietz WH, Jr., Gortmaker SL. 1985. Do We Fatten Our Children at the Television Set? Obesity and Television Viewing in Children and Adolescents. Pediatrics 75: 80712.

Donnerstein E, Slaby RG, Eron LD. 1994. The Mass Media and Youth Aggression. In Reason to Hope: A Psychosocial Perspective on Violence and Youth, ed. LD Eron, JH Gentry, P Schlegel. Washington, DC: American Psychological Association.

Flegal KM, Graubard BI, Williamson DF, Gail MH. 2005. Excess Deaths Associated with Underweight, Overweight, and Obesity. Journal of the American Medical Association 293: 1861-67.

Finkelstein EA, Fiebelkorn IC, Wang G. 2003. National Medical Spending Attributable to Overweight and Obesity: How Much, and Who's Paying? Health Affairs (Millwood) Suppl Web Exclusives: W3-219-26.

French S, Harnack L, Jeffery R. 2000. Fast Food Restaurant Use Among Women in the Pound of Prevention Study: Dietary, Behavioral, and Demographic Correlates. International Journal of Obesity 24: 1353-59.

Gallo AE. 1999. Food Advertising in the United States. In America's Eating Habits: Changes and Consequences, ed. E Frazao, pp. 173-80. Washington, DC: United States Department of Agriculture.

Giammattei J, Blix G, Marshak HH, Wollitzer AO, Pettitt DJ. 2003. Television Watching and Soft Drink Consumption: Associations With Obesity in 11- to 13-Year-Old Schoolchildren. Archives of Pediatrics \& Adolescent Medicine 157: 882-6.

Gortmaker SL, Must A, Sobol AM, Peterson K, Colditz GA, Dietz WH. 1996. Television Viewing As a Cause of Increasing Obesity Among Children in the United States, 1986-1990. Archives of Pediatrics \& Adolescent Medicine 150: 356-62.

Hancox RJ, Milne BJ, Poulton R. 2004. Association Between Child and Adolescent Television Viewing and Adult Health: A Longitudinal Birth Cohort Study. Lancet 364: 257-62.

Hill JO, Peters JC. 1998. Environmental Contributions to the Obesity Epidemic. Science 280: 1371-4.

Huston AC. 1992. Big World, Small Screen: The Role of Television in American Society. Lincoln: University of Nebraska Press. 195 pp. 
Kaiser Family Foundation. 2004. The Role of Media In Childhood Obesity, Menlo Park, CA.

Krebs NF, Jacobson MS. 2003. Prevention of Pediatric Overweight and Obesity. Pediatrics 112: 424-30.

Kuczmarski RJ, Ogden CL, Guo SS, et al. 2002. 2000 CDC Growth Charts for the United States: Methods and Development. National Center for Health Statistics. Vital Health Stat 11(246).

Kunkel D. 2001. Children and Television Advertising. In Handbook of Children and the Media, ed. DGSaJL Singer, pp. 375-93. Thousand Oaks, CA: Sage Publications.

Mayer CE. 2005. Kraft to Curb Snack Food Advertising. Washington Post January 12: E01.

McGinnis JM, Foege WH. 1993. Actual Causes of Death in the United States. Journal of the American Medical Association 270: 2207-12.

Nestle M. 2002. Food Politics: How the Food Industry Influences Nutrition and Health. Berkeley: University of California Press. xii, 457 pp.

Ogden CL, Flegal KM, Carroll MD, Johnson CL. 2002. Prevalence and Trends in Overweight among US Children, 1999-2000. Journal of the American Medical Association 288: 1728-32.

Orzechowski W, Walker R. 2002. The Tax Burden on Tobacco: Volume 36, 2001. Arlington, VA: Orzechowski and Walker.

Proctor MH, Moore LL, Gao D, Cupples LA, Bradlee ML, Hood MY, Ellison RC. 2003. Television Viewing and Change in Body Fat from Preschool to Early Adolescence: The Framingham Children's Study. International Journal of Obesity and Related Metabolic Disorders 27: 827-33.

Robinson TN. 1999. Reducing Children's Television Viewing to Prevent Obesity: A Randomized Controlled Trial. Journal of the American Medical Association 282: $1561-7$.

Robinson TN, Hammer LD, Killen JD, Kraemer HC, Wilson DM, Hayward C, Taylor CB. 1993. Does Television Viewing Increase Obesity and Reduce Physical Activity? Cross-Sectional and Longitudinal Analyses Among Adolescent Girls. Pediatrics 91: 273-80.

Saffer H. 1997. Alcohol Advertising and Motor Vehicle Fatalities. Review of Economics and Statistics 79: 431-42.

Saffer H, Dave D. 2003. Alcohol Advertising and Alcohol Consumption by Adolescents. National Bureau of Economic Research, Inc, NBER Working Paper 9676. 
Simon JL, Arndt J. 1980. The Shape of the Advertising Response Function. Journal of Advertising Research 20: 11-28.

Squires S. 1998. Obesity-Linked Diabetes Rising in Children. In Washington Post November 3.

Staiger D, Stock JA. 1997. Instrumental Variables Regressions with Weak Instruments. Econometrica 65, 557-86.

Tellis GJ, Chandy RK, Thaivanich P. 2000. Which Ad Works, When, Where, and How Often? Modeling the Effects of Direct Television Advertising. Journal of Marketing Research 37: 32-46.

Tellis GJ, Weiss DL. 1995. Does TV Advertising Really Affect Sales? The Role of Measures, Models, and Data Aggregation. Journal of Advertising 24: 1-12

US Department of Health and Human Services. 2001. The Surgeon General's Call to Action to Prevent and Decrease Overweight and Obesity, US Department of Health and Human Services, Public Health Service, Office of the Surgeon General, Rockville, MD. 


\section{Table 1a}

Trends in Body Mass Index and the Percentage Overweight, Persons 3 to 11 Years of Age

\begin{tabular}{|ll|cc|cc|cc|}
\hline & & & & \multicolumn{2}{|c|}{ Males only } & \multicolumn{2}{|c|}{ Females only } \\
\hline Survey & Period & BMI $^{\mathrm{b}}$ & Overweight $^{\mathrm{c}}$ & $\mathrm{BMI}^{\mathrm{b}}$ & Overweight $^{\mathrm{c}}$ & BMI $^{\mathrm{b}}$ & Overweight $^{\mathrm{c}}$ \\
NHES II & $1963-1965$ & 16.63 & 4.24 & 16.57 & 4.00 & 16.68 & 4.50 \\
NHANES I & $1971-1974$ & 16.44 & 5.33 & 16.46 & 5.74 & 16.42 & 4.92 \\
NHANES II & $1976-1980$ & 16.64 & 7.33 & 16.64 & 7.22 & 16.64 & 7.44 \\
NHANES III & $1988-1994$ & 17.15 & 10.59 & 17.09 & 10.25 & 17.22 & 10.95 \\
NHANES 99 & $1999-2000$ & 17.37 & 14.26 & 17.38 & 14.74 & 17.36 & 13.76 \\
\hline
\end{tabular}

${ }^{a}$ The surveys are as follows: National Health Examination Survey II (NHES II), National Health and Nutrition Examination Survey I (NHANES I), National Health and Nutrition Examination Survey II (NHANES II), National Health and Nutrition Examination Survey III (NHANES III), and National Health and Nutrition Examination Survey 1999-2000 (NHANES 99). NHES II pertains to children 6-11 years of age. Survey weights are employed in all computations.

${ }^{\mathrm{b}}$ Weight in kilograms divided by height in meters squared. Actual weights and heights are used in calculations.

${ }^{c}$ Percentage with BMI equal to or greater than the $95^{\text {th }}$ percentile based on Centers for Disease Control and Prevention growth charts. See http://www.cdc.gov/growthcharts. 


\section{Table 1b}

Trends in Body Mass Index and the Percentage Overweight, Persons 12 to 18 Years of $\mathrm{Age}^{\mathrm{a}}$

\begin{tabular}{|c|c|c|c|c|c|c|c|}
\hline & & & & \multicolumn{2}{|c|}{ Males only } & \multicolumn{2}{|c|}{ Females only } \\
\hline Survey & Period & $\mathrm{BMI}^{\mathrm{b}}$ & Overweight $^{\mathrm{c}}$ & $\mathrm{BMI}^{\mathrm{b}}$ & Overweight $^{\mathrm{c}}$ & $\mathrm{BMI}^{\mathrm{b}}$ & Overweight $^{\mathrm{c}}$ \\
\hline NHES I,III & $\begin{array}{l}1959-1962, \\
1966-1970\end{array}$ & 20.61 & 4.45 & 20.47 & 4.50 & 20.76 & 4.40 \\
\hline NHANES I & 1971-1974 & 20.97 & 6.82 & 20.81 & 6.83 & 21.13 & 6.82 \\
\hline NHANES II & $1976-1980$ & 21.03 & 5.63 & 20.92 & 5.39 & 21.16 & 5.89 \\
\hline NHANES III & 1988-1994 & 22.11 & 10.62 & 21.95 & 11.48 & 22.28 & 9.72 \\
\hline NHANES 99 & $1999-2000$ & 22.82 & 14.75 & 22.52 & 15.03 & 23.13 & 14.45 \\
\hline
\end{tabular}

${ }^{a}$ The surveys are as follows: National Health Examination Survey I and III (NHES I,III), National Health and Nutrition Examination Survey I (NHANES I), National Health and Nutrition Examination Survey II (NHANES II), National Health and Nutrition Examination Survey III (NHANES III), and National Health and Nutrition Examination Survey 1999-2000 (NHANES 99). NHES I was used for adolescents aged 18, while NHES III was used for those between the ages of 12 and 17. Survey weights are employed in all computations.

${ }^{\mathrm{b}}$ Weight in kilograms divided by height in meters squared. Actual weights and heights are used in calculations.

${ }^{c}$ Percentage with BMI equal to or greater than the $95^{\text {th }}$ percentile based on Centers for Disease Control and Prevention growth charts. See http://www.cdc.gov/growthcharts. 


\section{Table 2a}

Definitions, Means, and Standard Deviations of Dependent Variables

\begin{tabular}{|c|c|c|c|c|c|c|c|}
\hline \multirow[t]{2}{*}{ Variable } & \multirow[t]{2}{*}{ Definition } & \multicolumn{6}{|c|}{ Mean (Standard Deviation) } \\
\hline & & \multicolumn{3}{|c|}{ Ages 3-11 (NLSY79) } & \multicolumn{3}{|c|}{ Ages 12-18 (NLSY97) } \\
\hline & & $\begin{array}{l}\text { Whole } \\
\text { Sample }\end{array}$ & Male & Female & $\begin{array}{l}\text { Whole } \\
\text { Sample }\end{array}$ & Male & Female \\
\hline Body mass index & $\begin{array}{l}\text { Weight in kilograms divided by height } \\
\text { in meters squared }\end{array}$ & $\begin{array}{l}17.603 \\
(4.643)\end{array}$ & $\begin{array}{l}17.690 \\
(4.502)\end{array}$ & $\begin{array}{l}17.513 \\
(4.785)\end{array}$ & $\begin{array}{l}22.114 \\
(4.429)\end{array}$ & $\begin{array}{l}22.554 \\
(4.590)\end{array}$ & $\begin{array}{l}21.655 \\
(4.207)\end{array}$ \\
\hline Overweight & $\begin{array}{l}\text { Dichotomous variable that equals } 1 \text { if } \\
\text { the body mass index is equal to or } \\
\text { greater than the } 95^{\text {th }} \text { percentile }\end{array}$ & $\begin{array}{c}0.156 \\
(0.363)\end{array}$ & $\begin{array}{c}0.174 \\
(0.379)\end{array}$ & $\begin{array}{c}0.137 \\
(0.344)\end{array}$ & $\begin{array}{c}0.104 \\
(0.305)\end{array}$ & $\begin{array}{c}0.137 \\
(0.343)\end{array}$ & $\begin{array}{c}0.069 \\
(0.254)\end{array}$ \\
\hline Sample size (person-year) & & 6,322 & 3,228 & 3,094 & 6,818 & 3,527 & 3,291 \\
\hline
\end{tabular}


Table 2b

Definitions, Means, and Standard Deviations of Explanatory Variables and Instrumental Variables

\begin{tabular}{|c|c|c|c|}
\hline \multirow[t]{2}{*}{ Variable } & \multirow[t]{2}{*}{ Definition } & \multicolumn{2}{|c|}{ Mean (Standard Deviation) } \\
\hline & & $\begin{array}{l}\text { Ages 3-11 } \\
\text { (NLSY79) }\end{array}$ & $\begin{array}{l}\text { Ages 12-18 } \\
\text { (NLSY97) }\end{array}$ \\
\hline TV Time (TV) & $\begin{array}{l}\text { Time spent by child watching television } \\
\text { (in hours per week) }\end{array}$ & $\begin{array}{c}25.391 \\
(25.529)\end{array}$ & $\begin{array}{l}18.754 \\
(14.547)\end{array}$ \\
\hline Messages seen & $\begin{array}{l}\text { Hours of fast-food restaurant } \\
\text { advertising messages seen per week in } \\
\text { respondent's Designated Market Area } \\
\text { (see text for more details) }\end{array}$ & $(0.593)$ & $(0.413)$ \\
\hline Messages aired & $\begin{array}{l}\text { Hours of fast-food restaurant } \\
\text { advertising messages aired per week in } \\
\text { respondent's Designated Market Area }\end{array}$ & $\begin{array}{c}3.507 \\
(1.195)\end{array}$ & $\begin{array}{c}3.809 \\
(1.406)\end{array}$ \\
\hline Age & Age of respondent & $\begin{array}{c}7.288 \\
(2.546)\end{array}$ & $\begin{array}{l}14.779 \\
(1.392)\end{array}$ \\
\hline Hispanic & $\begin{array}{l}\text { Dichotomous variable that equals } 1 \text { if } \\
\text { respondent is Hispanic }\end{array}$ & $\begin{array}{c}0.059 \\
(0.236)\end{array}$ & $\begin{array}{c}0.111 \\
(0.314)\end{array}$ \\
\hline Black non-Hispanic & $\begin{array}{l}\text { Dichotomous variable that equals } 1 \text { if } \\
\text { respondent is black but not Hispanic }\end{array}$ & $\begin{array}{l}0.125 \\
(0.331)\end{array}$ & $\begin{array}{c}0.156 \\
(0.363)\end{array}$ \\
\hline Other race & $\begin{array}{l}\text { Dichotomous variable if respondent's } \\
\text { race is other than white, black, or } \\
\text { Hispanic }\end{array}$ & $(---)$ & $\begin{array}{c}0.013 \\
(0.113)\end{array}$ \\
\hline Male & $\begin{array}{l}\text { Dichotomous variable that equals } 1 \text { if } \\
\text { respondent is male }\end{array}$ & $\begin{array}{c}0.511 \\
(0.500)\end{array}$ & $\begin{array}{c}0.510 \\
(0.500)\end{array}$ \\
\hline Family income & $\begin{array}{l}\text { Real household income in tens of } \\
\text { thousands of } 1982-84 \text { dollars }\end{array}$ & $\begin{array}{c}7.159 \\
(10.521)\end{array}$ & $\begin{array}{c}5.499 \\
(4.220)\end{array}$ \\
\hline Income missing & $\begin{array}{l}\text { Dichotomous variable that equals } 1 \text { if } \\
\text { family income is missing }\end{array}$ & $\begin{array}{c}0.036 \\
(0.185)\end{array}$ & $\begin{array}{c}0.133 \\
(0.339)\end{array}$ \\
\hline $\begin{array}{l}\text { Weight reported by } \\
\text { mother }\end{array}$ & $\begin{array}{l}\text { Dichotomous variable that equals } 1 \text { if } \\
\text { weight is reported by mother }\end{array}$ & $\begin{array}{c}0.283 \\
(0.450)\end{array}$ & $\begin{array}{l}-- \\
(---)\end{array}$ \\
\hline $\begin{array}{l}\text { Height reported by } \\
\text { mother }\end{array}$ & $\begin{array}{l}\text { Dichotomous variable that equals } 1 \text { if } \\
\text { height is reported by mother }\end{array}$ & $\begin{array}{c}0.233 \\
(0.423)\end{array}$ & $(---)$ \\
\hline Mother overweight & $\begin{array}{l}\text { Dichotomous variable that equals } 1 \text { if } \\
\text { mother's body mass index is equal to or } \\
\text { greater than } 25 \mathrm{~kg} / \mathrm{m}^{2}\end{array}$ & $\begin{array}{c}0.480 \\
(0.500)\end{array}$ & $\begin{array}{c}0.495 \\
(0.500)\end{array}$ \\
\hline Mother obese & $\begin{array}{l}\text { Dichotomous variable that equals } 1 \text { if } \\
\text { mother's body mass index is equal to or } \\
\text { greater than } 30 \mathrm{~kg} / \mathrm{m}^{2}\end{array}$ & $\begin{array}{c}0.217 \\
(0.412)\end{array}$ & $\begin{array}{c}0.210 \\
(0.408)\end{array}$ \\
\hline Mother employment & $\begin{array}{l}\text { Dichotomous variable that equals } 1 \text { if } \\
\text { mother is employed }\end{array}$ & $\begin{array}{c}0.692 \\
(0.462)\end{array}$ & $\begin{array}{c}0.711 \\
(0.453)\end{array}$ \\
\hline Yr98 & $\begin{array}{l}\text { Dichotomous variable that equals } 1 \text { if } \\
\text { year=1998 }\end{array}$ & $\begin{array}{c}0.340 \\
(0.474)\end{array}$ & $\begin{array}{c}0.337 \\
(0.473)\end{array}$ \\
\hline
\end{tabular}




\begin{tabular}{|c|c|c|c|}
\hline Yr99 & $\begin{array}{l}\text { Dichotomous variable that equals } 1 \text { if } \\
\text { year=1999 }\end{array}$ & $\begin{array}{l}--- \\
(---)\end{array}$ & $\begin{array}{c}0.345 \\
(0.475)\end{array}$ \\
\hline Yr00 & $\begin{array}{l}\text { Dichotomous variable that equals } 1 \text { if } \\
\text { year }=2000\end{array}$ & $\begin{array}{c}0.295 \\
(0.456)\end{array}$ & $\begin{array}{l}--- \\
(---)\end{array}$ \\
\hline Fast-food restaurants & $\begin{array}{l}\text { Number of fast-food restaurants per } \\
10,000 \text { persons in respondent's state of } \\
\text { residence }\end{array}$ & $\begin{array}{l}7.118 \\
(0.565)\end{array}$ & $\begin{array}{c}7.228 \\
(0.490)\end{array}$ \\
\hline $\begin{array}{l}\text { Full-service } \\
\text { restaurants }\end{array}$ & $\begin{array}{l}\text { Number of full-service restaurants per } \\
10,000 \text { persons in respondent's state of } \\
\text { residence }\end{array}$ & $\begin{array}{c}7.147 \\
(0.927)\end{array}$ & $\begin{array}{c}7.233 \\
(1.001)\end{array}$ \\
\hline Cigarette price & $\begin{array}{l}\text { Real cigarette price in respondent's } \\
\text { state of residence in } 1982-1984 \text { dollars }\end{array}$ & $\begin{array}{l}2.487 \\
(0.533)\end{array}$ & $\begin{array}{l}2.525 \\
(0.495)\end{array}$ \\
\hline Government & $\begin{array}{l}\text { Dichotomous variable that equals } 1 \text { if } \\
\text { smoking is prohibited in government } \\
\text { workplaces in respondent's state of } \\
\text { residence }\end{array}$ & $\begin{array}{c}0.883 \\
(0.321)\end{array}$ & $\begin{array}{c}0.864 \\
(0.342)\end{array}$ \\
\hline Private & $\begin{array}{l}\text { Dichotomous variable that equals } 1 \text { if } \\
\text { smoking is prohibited in private } \\
\text { workplaces in respondent's state of } \\
\text { residence }\end{array}$ & $\begin{array}{c}0.551 \\
(0.497)\end{array}$ & $\begin{array}{c}0.453 \\
(0.498)\end{array}$ \\
\hline Restaurant & $\begin{array}{l}\text { Dichotomous variable that equals } 1 \text { if } \\
\text { smoking is prohibited in restaurants in } \\
\text { respondent's state of residence }\end{array}$ & $\begin{array}{c}0.682 \\
(0.466)\end{array}$ & $\begin{array}{c}0.657 \\
(0.475)\end{array}$ \\
\hline Other & $\begin{array}{l}\text { Dichotomous variable that equals } 1 \text { if } \\
\text { smoking is prohibited in other public } \\
\text { places in respondent's state of residence }\end{array}$ & $\begin{array}{c}0.924 \\
(0.265)\end{array}$ & $\begin{array}{c}0.923 \\
(0.267)\end{array}$ \\
\hline $\begin{array}{l}\text { Full-service } \\
\text { restaurant price }\end{array}$ & $\begin{array}{l}\text { Real full-service restaurant meal price } \\
\text { in respondent's state of residence in } \\
\text { 1982-1984 dollars }\end{array}$ & $\begin{array}{l}9.000 \\
(1.875)\end{array}$ & $\begin{array}{c}9.260 \\
(1.980)\end{array}$ \\
\hline $\begin{array}{l}\text { Fast-food restaurant } \\
\text { price }\end{array}$ & $\begin{array}{l}\text { Real fast-food restaurant meal price in } \\
\text { respondent's state of residence in 1982- } \\
1984 \text { dollars }\end{array}$ & $\begin{array}{c}4.530 \\
(0.267)\end{array}$ & $\begin{array}{c}4.559 \\
(0.250)\end{array}$ \\
\hline Food at home price & $\begin{array}{l}\text { Real food at home price in respondent's } \\
\text { state of residence in 1982-1984 dollars }\end{array}$ & $\begin{array}{l}2.013 \\
(0.231)\end{array}$ & $\begin{array}{l}2.026 \\
(0.267)\end{array}$ \\
\hline $\begin{array}{l}\text { ample size } \\
\text { erson-year) } \\
\text { strumental Variable }\end{array}$ & & 6,322 & 6,818 \\
\hline $\begin{array}{l}\text { Price of } \\
\text { advertisement } \\
\text { Number of } \\
\text { households with TV }\end{array}$ & $\begin{array}{l}\text { Real dollar expenditures per second of } \\
\text { exposure } \\
\text { Number of households in respondent's } \\
\text { designated market area owning a TV set } \\
\text { in hundreds of thousands }\end{array}$ & $\begin{array}{c}3.184 \\
(2.811) \\
1.648 \\
(1.591)\end{array}$ & $\begin{array}{c}3.358 \\
(2.593) \\
1.752 \\
(1.544)\end{array}$ \\
\hline $\begin{array}{l}\text { Average annual } \\
\text { temperature }\end{array}$ & $\begin{array}{l}\text { Mean } 1976 \text { temperature in respondent's } \\
\text { county of residence }\end{array}$ & $\begin{array}{l}55.368 \\
(7.678)\end{array}$ & $\begin{array}{l}55.683 \\
(6.996)\end{array}$ \\
\hline erson-year) & & 6,288 & 6,743 \\
\hline
\end{tabular}


Table 3

Regression Results

Dependent Variable: Body Mass Index ${ }^{\mathrm{a}}$

\begin{tabular}{|c|c|c|c|c|c|c|}
\hline & \multicolumn{6}{|c|}{ Ages 3-11 (NLSY79) } \\
\hline & \multicolumn{3}{|c|}{ Specification 1} & \multicolumn{3}{|c|}{ Specification 2} \\
\hline & Whole & Male & Female & Whole & Male & Female \\
\hline \multirow[t]{2}{*}{ Messages seen } & $0.442 * *$ & $0.598^{*}$ & 0.247 & $0.315 * * *$ & $0.313 * *$ & $0.319 * * *$ \\
\hline & $(1.859)$ & $(1.637)$ & $(1.063)$ & $(2.843)$ & $(1.754)$ & $(3.058)$ \\
\hline \multirow[t]{2}{*}{ TV time (10 hours) } & -0.031 & -0.068 & 0.018 & & & \\
\hline & $(0.611)$ & $(0.923)$ & $(0.341)$ & & & \\
\hline \multicolumn{7}{|l|}{ Other variables } \\
\hline Individual variables $^{b}$ & Yes & Yes & Yes & Yes & Yes & Yes \\
\hline DMA fixed effects & Yes & Yes & Yes & Yes & Yes & Yes \\
\hline Year fixed effects & Yes & Yes & Yes & Yes & Yes & Yes \\
\hline State variables ${ }^{\mathrm{c}}$ & Yes & Yes & Yes & Yes & Yes & Yes \\
\hline Sample & 6,322 & 3,228 & 3,094 & 6,322 & 3,228 & 3,094 \\
\hline \multirow[t]{4}{*}{ R-squared } & 0.148 & 0.173 & 0.158 & 0.148 & 0.173 & 0.158 \\
\hline & \multicolumn{6}{|c|}{ Ages 12-18 (NLSY97) } \\
\hline & \multicolumn{3}{|c|}{ Specification 1} & \multicolumn{3}{|c|}{ Specification 2} \\
\hline & Whole & Male & Female & Whole & Male & Female \\
\hline \multirow[t]{2}{*}{ Messages seen } & -0.089 & -0.097 & -0.032 & $0.881 * * *$ & $0.970 * * *$ & $0.731 * * *$ \\
\hline & $(0.240)$ & $(0.256)$ & $(0.050)$ & $(4.193)$ & $(3.421)$ & $(2.573)$ \\
\hline \multirow[t]{2}{*}{ TV time (10 hours) } & $0.282 * * *$ & $0.312 * * *$ & $0.223^{*}$ & & & \\
\hline & $(2.632)$ & $(2.202)$ & $(1.363)$ & & & \\
\hline \multicolumn{7}{|l|}{ Other variables } \\
\hline Individual variables $^{b}$ & Yes & Yes & Yes & Yes & Yes & Yes \\
\hline DMA fixed effects & Yes & Yes & Yes & Yes & Yes & Yes \\
\hline Year fixed effects & Yes & Yes & Yes & Yes & Yes & Yes \\
\hline State variables ${ }^{\mathrm{c}}$ & Yes & Yes & Yes & Yes & Yes & Yes \\
\hline Sample size & 6,818 & 3,527 & 3,291 & 6,818 & 3,527 & 3,291 \\
\hline R-squared & 0.192 & 0.193 & 0.235 & 0.190 & 0.191 & 0.234 \\
\hline
\end{tabular}

${ }^{a}$ All regressions are weighted by NLSY sampling weights. T-ratios are reported in parentheses. *** Significant at the $1 \%$ level (one tailed test). ** Significant at the 5\% level (one tailed test). * Significant at the $10 \%$ level (one tailed test). Regressions are clustered by DMA.

${ }^{\mathrm{b}}$ Individual variables include age, black non-Hispanic, Hispanic, other race (NLSY97 only), male, family income, missing income dummy, mother overweight, mother obese, mother employed, and dummies for weight and height reported by mothers (as opposed to actual measurements NLSY79 only).

${ }^{\mathrm{c}}$ State variables include the per capita number of fast-food restaurants, per capita number of fullservice restaurants, real cigarette price, dummies for clean indoor air laws, real full-service restaurant price, real food at home price, and real fast-food restaurant price. 
Table 4

Regression Results

Dependent Variable: Overweight ${ }^{\mathrm{a}}$

\begin{tabular}{|c|c|c|c|c|c|c|}
\hline & \multicolumn{6}{|c|}{ Ages 3-11 (NLSY79) } \\
\hline & \multicolumn{3}{|c|}{ Specification 1} & \multicolumn{3}{|c|}{ Specification 2} \\
\hline & Whole & Male & Female & Whole & Male & Female \\
\hline \multirow[t]{2}{*}{ Messages seen } & 0.010 & 0.035 & -0.018 & $0.026 * * *$ & $0.032 * *$ & $0.021 * *$ \\
\hline & $(0.454)$ & $(1.026)$ & $(0.681)$ & $(2.533)$ & $(1.856)$ & $(2.002)$ \\
\hline \multirow[t]{2}{*}{ TV time (10 hours) } & 0.004 & -0.001 & $0.010 *$ & & & \\
\hline & $(0.811)$ & $(0.139)$ & $(1.346)$ & & & \\
\hline \multicolumn{7}{|l|}{ Other variables } \\
\hline Individual variables $^{\mathrm{b}}$ & Yes & Yes & Yes & Yes & Yes & Yes \\
\hline DMA fixed effects & Yes & Yes & Yes & Yes & Yes & Yes \\
\hline Year fixed effects & Yes & Yes & Yes & Yes & Yes & Yes \\
\hline State variables $^{\mathrm{c}}$ & Yes & Yes & Yes & Yes & Yes & Yes \\
\hline Sample & 6322 & 3228 & 3094 & 6322 & 3228 & 3094 \\
\hline \multirow[t]{4}{*}{ R-squared } & 0.088 & 0.101 & 0.101 & 0.088 & 0.101 & 0.101 \\
\hline & \multicolumn{6}{|c|}{ Ages 12-18 (NLSY97) } \\
\hline & \multicolumn{3}{|c|}{ Specification 1} & \multicolumn{3}{|c|}{ Specification 2} \\
\hline & Whole & Male & Female & Whole & Male & Female \\
\hline \multirow[t]{2}{*}{ Messages seen } & 0.005 & -0.007 & 0.015 & $0.040 * * *$ & $0.064 * * *$ & 0.011 \\
\hline & $(0.201)$ & $(0.220)$ & $(0.511)$ & $(2.724)$ & $(2.985)$ & $(0.746)$ \\
\hline \multirow[t]{2}{*}{ TV time (10 hours) } & 0.010 & $0.021 * *$ & -0.001 & & & \\
\hline & $(1.216)$ & $(2.005)$ & $(0.112)$ & & & \\
\hline \multicolumn{7}{|l|}{ Other variables } \\
\hline Individual variables $^{b}$ & Yes & Yes & Yes & Yes & Yes & Yes \\
\hline DMA fixed effects & Yes & Yes & Yes & Yes & Yes & Yes \\
\hline Year fixed effects & Yes & Yes & Yes & Yes & Yes & Yes \\
\hline State variables $^{\mathrm{c}}$ & Yes & Yes & Yes & Yes & Yes & Yes \\
\hline Sample size & 6,818 & 3,527 & 3,291 & 6,818 & 3,527 & 3,291 \\
\hline R-squared & 0.096 & 0.103 & 0.125 & 0.096 & 0.102 & 0.125 \\
\hline
\end{tabular}

${ }^{a}$ All regressions are weighted by NLSY sampling weights. T-ratios are reported in parentheses. *** Significant at the $1 \%$ level (one tailed test). ** Significant at the 5\% level (one tailed test). * Significant at the $10 \%$ level (one tailed test). Regressions are clustered by DMA.

${ }^{\mathrm{b}}$ Individual variables include age, black non-Hispanic, Hispanic, other race (NLSY97 only), male, family income, missing income dummy, mother overweight, mother obese, mother employed, and dummies for weight and height reported by mothers (as opposed to actual measurements NLSY79 only).

${ }^{\mathrm{c}}$ State variables include the per capita number of fast-food restaurants, per capita number of fullservice restaurants, real cigarette price, dummies for clean indoor air laws, real full-service restaurant price, real food at home price, and real fast-food restaurant price. 
Table 5

Instrumental Variable Regression Results Endogenous Variable: Messages Seen (Specification 2) ${ }^{\mathrm{a}}$

\begin{tabular}{|c|c|c|c|c|c|c|}
\hline & \multicolumn{3}{|c|}{ Ages 3-11 (NLSY79) } & \multicolumn{3}{|c|}{ Ages 12-18 (NLSY97) } \\
\hline & Whole & Male & Female & Whole & Male & Female \\
\hline \multicolumn{7}{|c|}{ Panel A: IV Test Results (Dependent Variable: Body Mass Index) } \\
\hline Durbin-Wu-Hausman endogeneity test $\chi^{2}(1)$ & 0.592 & 0.284 & 0.400 & 2.158 & 2.183 & 0.134 \\
\hline Reject the null at $5 \%$ level? & No & No & No & No & No & No \\
\hline Hansen $\mathbf{J}$ statistic overidentification test $\chi^{2}(3)$ & 0.008 & 0.174 & 0.169 & 0.308 & 0.889 & 0.056 \\
\hline Reject the null at $5 \%$ level? & No & No & No & No & No & No \\
\hline \multicolumn{7}{|l|}{ Panel B: IV Test Results (Dependent Variable: Overweight) } \\
\hline Durbin-Wu-Hausman endogeneity test $\chi^{2}(1)$ & 1.552 & 1.477 & 0.148 & 0.407 & 0.456 & 0.183 \\
\hline Reject the null at $5 \%$ level? & No & No & No & No & No & No \\
\hline Hansen $\mathbf{J}$ statistic overidentification test $\chi^{2}(3)$ & 2.442 & 1.171 & 1.240 & 0.011 & 0.004 & 0.198 \\
\hline Reject the null at $5 \%$ level? & No & No & No & No & No & No \\
\hline \multicolumn{7}{|l|}{ Panel C: First stage results (Partial results are reported) ${ }^{\mathrm{b}}$} \\
\hline Price of advertisement & $\begin{array}{l}-0.148 * * * \\
(10.937)\end{array}$ & $\begin{array}{l}-0.145 * * * \\
(11.035)\end{array}$ & $\begin{array}{l}-0.156 * * * \\
(6.898)\end{array}$ & $\begin{array}{l}-0.060 * * * \\
(11.322)\end{array}$ & $\begin{array}{l}-0.068 * * * \\
(10.038)\end{array}$ & $\begin{array}{l}-0.056^{* * * *} \\
(8.183)\end{array}$ \\
\hline Number of households with TV in the DMA $(000,000)$ & $\begin{array}{c}0.100 * \\
(1.563)\end{array}$ & $\begin{array}{c}0.108 * \\
(1.511)\end{array}$ & $\begin{array}{c}0.102 \\
(1.140)\end{array}$ & $\begin{array}{l}0.300 * * * \\
(4.185)\end{array}$ & $\begin{array}{l}0.268 * * * \\
(3.592)\end{array}$ & $\begin{array}{l}0.348 * * * \\
(4.498)\end{array}$ \\
\hline Average annual temperature & $\begin{array}{c}4.711 \\
(0.857)\end{array}$ & $\begin{array}{c}9.701 * \\
(1.313)\end{array}$ & $\begin{array}{l}-0.662 \\
(0.096)\end{array}$ & $\begin{array}{c}1.366 \\
(0.593)\end{array}$ & $\begin{array}{c}1.467 \\
(0.326)\end{array}$ & $\begin{array}{l}-0.456 \\
(0.072)\end{array}$ \\
\hline Sample size & 6,288 & 3,211 & 3,077 & 6,743 & 3,496 & 3,247 \\
\hline R-squared & 0.181 & 0.189 & 0.196 & 0.266 & 0.271 & 0.309 \\
\hline F test of the excluded instruments & 41.922 & 46.539 & 19.018 & 51.466 & 37.051 & 25.553 \\
\hline
\end{tabular}

${ }^{a}$ All regressions are weighted by NLSY sampling weights. T-ratios are reported in parentheses. *** Significant at the $1 \%$ level (one tailed test). ** Significant at the 5\% level (one tailed test). * Significant at the $10 \%$ level (one tailed test). Regressions are clustered by DMA. All regressions include individual characteristics, DMA and year fixed effects, and other state variables (Specification 2).

${ }^{\mathrm{b}}$ First stage regressions also include individual characteristics, DMA and year fixed effects, and other state variables. Dependent variable in the first stage regression is messages seen. 
Table 6

Regression Results Using Messages Aired in Respondent's DMA ${ }^{\mathrm{a}}$

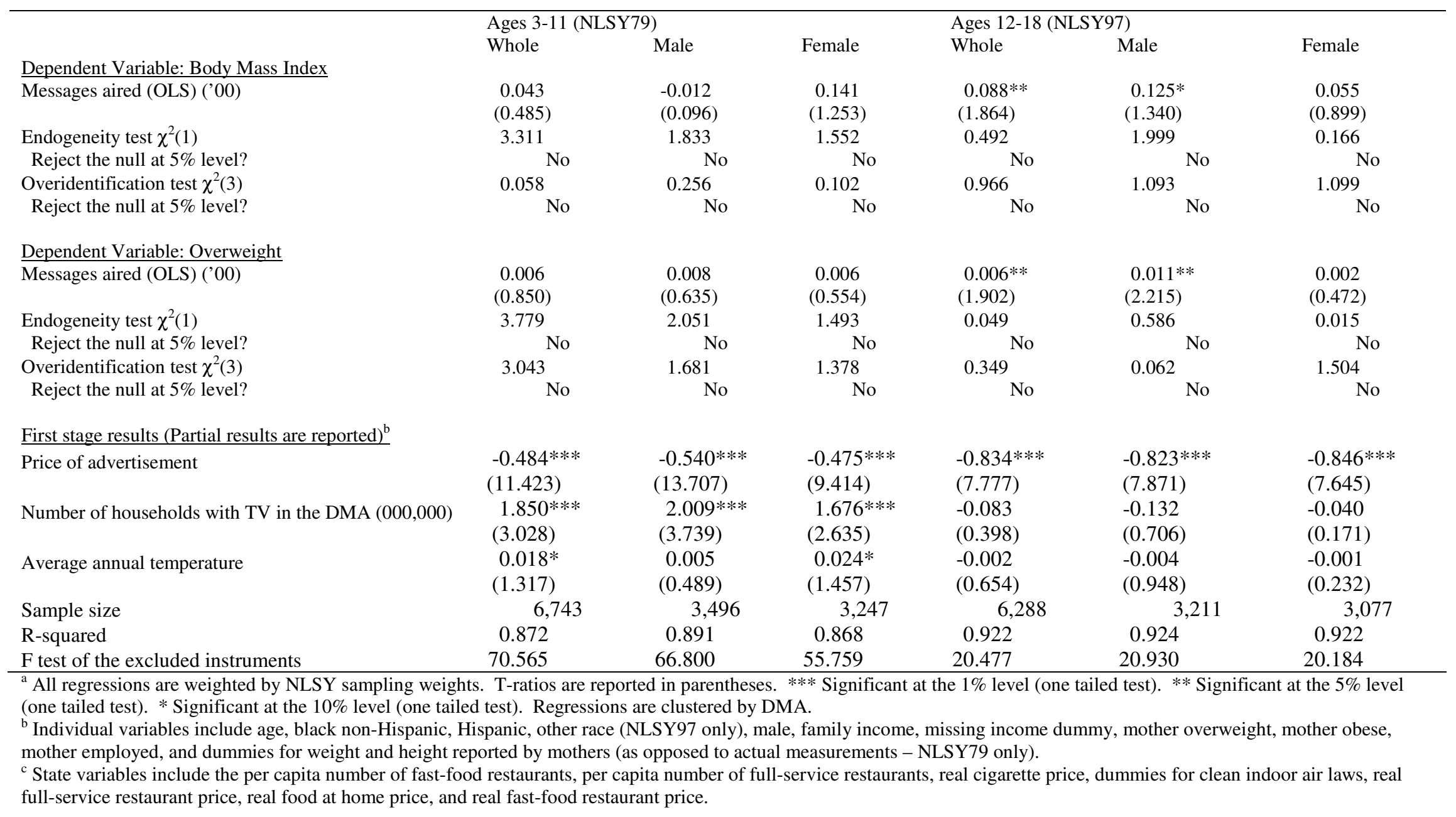




\section{Table A1}

Complete Regression Results for Children Aged 3-11 (Specification 2 of Tables 3 and 4) ${ }^{\mathrm{a}}$

\begin{tabular}{|c|c|c|c|c|c|c|}
\hline & \multicolumn{3}{|c|}{ Dep. Variable: Body Mass Index } & \multicolumn{3}{|c|}{ Dep. Variable: Overweight } \\
\hline & Whole & Male & Female & Whole & Male & Female \\
\hline \multirow[t]{2}{*}{ TV*exposure } & $0.315 * * *$ & $0.313^{*}$ & $0.319 * * *$ & $0.026 * *$ & $0.032 *$ & $0.021 * *$ \\
\hline & $(2.843)$ & $(1.754)$ & $(3.058)$ & $(2.533)$ & $(1.856)$ & $(2.002)$ \\
\hline \multirow[t]{2}{*}{ Age } & $0.429 * * *$ & $0.472 * * *$ & $0.399 * * *$ & $-0.006 * * *$ & -0.003 & $-0.009 * * *$ \\
\hline & $(15.365)$ & $(10.788)$ & $(13.147)$ & $(2.637)$ & $(0.987)$ & $(3.078)$ \\
\hline \multirow[t]{2}{*}{ Hispanic } & $0.646 * * *$ & $0.860 * * *$ & 0.515 & $0.073 * * *$ & $0.087 * * *$ & $0.061 *$ \\
\hline & $(3.039)$ & $(3.250)$ & $(1.644)$ & $(3.422)$ & $(2.756)$ & $(1.832)$ \\
\hline \multirow[t]{2}{*}{ Black } & $0.609 * * *$ & 0.345 & $0.902 * *$ & $0.057 * * *$ & 0.030 & $0.085 * * *$ \\
\hline & $(3.119)$ & $(1.179)$ & $(2.342)$ & $(3.255)$ & $(1.339)$ & $(3.058)$ \\
\hline \multirow[t]{2}{*}{ Male } & 0.103 & --- & --- & $0.037 * * *$ & --- & --- \\
\hline & $(0.646)$ & $(---)$ & $(---)$ & $(3.467)$ & $(---)$ & $(---)$ \\
\hline \multirow[t]{2}{*}{ Family Income } & $-0.013 * * *$ & $-0.011 * *$ & $-0.015 * *$ & $-0.001 * * *$ & $-0.001 * * *$ & $-0.001 * *$ \\
\hline & $(2.904)$ & $(1.961)$ & $(2.343)$ & $(4.723)$ & $(3.298)$ & $(2.360)$ \\
\hline \multirow[t]{2}{*}{ Income missing } & -0.486 & $-0.644 *$ & -0.301 & -0.030 & -0.023 & -0.039 \\
\hline & $(1.328)$ & $(1.692)$ & $(0.558)$ & $(0.914)$ & $(0.596)$ & $(0.838)$ \\
\hline \multirow[t]{2}{*}{ Mother overweight } & $0.689 * * *$ & $0.667 * * *$ & $0.717 * * *$ & $0.056 * * *$ & $0.055 * * *$ & $0.052 * *$ \\
\hline & $(3.940)$ & $(2.943)$ & $(2.795)$ & $(3.589)$ & $(2.747)$ & $(2.511)$ \\
\hline \multirow[t]{2}{*}{ Mother obese } & $0.836^{* * *} *$ & $0.560 * *$ & $1.124 * * *$ & $0.061 * * *$ & $0.053 * *$ & $0.070 * *$ \\
\hline & $(3.792)$ & $(2.055)$ & $(3.622)$ & $(3.344)$ & $(2.232)$ & $(2.526)$ \\
\hline \multirow[t]{2}{*}{ Mother employed } & -0.095 & -0.227 & 0.016 & 0.013 & 0.008 & 0.017 \\
\hline & $(0.550)$ & $(1.067)$ & $(0.062)$ & $(0.916)$ & $(0.393)$ & $(0.967)$ \\
\hline \multirow[t]{2}{*}{ Fast-food restaurants } & 0.750 & 1.115 & 0.387 & $0.048 * *$ & 0.056 & 0.038 \\
\hline & $(1.516)$ & $(1.577)$ & $(0.833)$ & $(1.966)$ & $(1.453)$ & $(1.023)$ \\
\hline \multirow[t]{2}{*}{ Full-service restaurants } & -0.075 & -0.292 & 0.130 & $-0.035 * *$ & -0.029 & $-0.041 * *$ \\
\hline & $(0.243)$ & $(0.715)$ & $(0.317)$ & $(2.074)$ & $(0.965)$ & $(2.147)$ \\
\hline \multirow[t]{2}{*}{ Cigarette price } & -1.073 & -1.129 & -1.104 & -0.023 & -0.030 & -0.046 \\
\hline & $(1.544)$ & $(1.174)$ & $(1.278)$ & $(0.486)$ & $(0.443)$ & $(0.690)$ \\
\hline \multirow[t]{2}{*}{ Government } & 0.802 & -0.095 & -0.330 & 0.031 & 0.084 & $-0.098 * *$ \\
\hline & $(0.984)$ & $(0.103)$ & $(0.497)$ & $(0.050)$ & $(0.034)$ & $(2.394)$ \\
\hline \multirow[t]{2}{*}{ Private } & -0.060 & -0.310 & $0.221 *$ & -0.002 & -0.012 & 0.005 \\
\hline & $(1.082)$ & $(0.359)$ & $(1.744)$ & $(0.299)$ & $(1.070)$ & $(1.423)$ \\
\hline \multirow[t]{2}{*}{ Restaurant } & -0.106 & 0.148 & -1.402 & $0.107 * *$ & 0.076 & 0.141 \\
\hline & $(0.106)$ & $(0.175)$ & $(0.608)$ & $(2.182)$ & $(1.385)$ & $(0.111)$ \\
\hline \multirow[t]{2}{*}{ Other } & -0.708 & 0.907 & 0.847 & -0.011 & 0.002 & $0.057 * *$ \\
\hline & $(0.158)$ & $(0.911)$ & $(0.299)$ & $(0.851)$ & $(0.198)$ & $(2.020)$ \\
\hline \multirow[t]{2}{*}{ Full-service restaurant price } & 0.125 & -0.093 & 0.418 & 0.009 & -0.001 & $0.025 * *$ \\
\hline & $(0.668)$ & $(0.306)$ & $(1.500)$ & $(0.803)$ & $(0.042)$ & $(2.127)$ \\
\hline \multirow[t]{2}{*}{ Fast-food restaurant price } & -0.659 & -1.023 & 0.025 & -0.046 & -0.074 & 0.000 \\
\hline & $(0.718)$ & $(1.027)$ & $(0.023)$ & $(0.736)$ & $(1.310)$ & $(0.002)$ \\
\hline \multirow[t]{2}{*}{ Food at home price } & 1.131 & $2.984 *$ & -1.436 & 0.089 & 0.120 & 0.040 \\
\hline & $(0.826)$ & $(1.694)$ & $(0.643)$ & $(1.446)$ & $(1.422)$ & $(0.488)$ \\
\hline Sample size & 6,322 & 3,228 & 3,094 & 6,322 & 3,228 & 3,094 \\
\hline R-squared & 0.148 & 0.173 & 0.158 & 0.088 & 0.101 & 0.101 \\
\hline
\end{tabular}

${ }^{\mathrm{a}}$ All regressions are weighted by NLSY sampling weights. T-ratios are reported in parentheses. Regressions are clustered by DMA. Regressions also include year and DMA fixed effects, and dummies for weight and height reported by mothers (as opposed to actual measurements). Intercepts are not shown. *** Significant at the $1 \%$ level (two tailed test). ${ }^{* *}$ Significant at the $5 \%$ level (two tailed test). * Significant at the $10 \%$ level (two tailed test). 


\section{Table A2}

Complete Regression Results for Adolescents Aged 12-18 (Specification 2 of Tables 3 and 4) ${ }^{\mathrm{a}}$

\begin{tabular}{|c|c|c|c|c|c|c|}
\hline & \multicolumn{3}{|c|}{ Dep. Variable: Body Mass Index } & \multicolumn{3}{|c|}{ Dep. Variable: Overweight } \\
\hline & Whole & Male & Female & Whole & Male & Female \\
\hline \multirow[t]{2}{*}{ TV*exposure } & $0.881 * * *$ & $0.970 * * *$ & $0.731 * *$ & $0.040 * * *$ & $0.064 * * *$ & 0.011 \\
\hline & $(4.193)$ & $(3.421)$ & $(2.573)$ & $(2.724)$ & $(2.985)$ & $(0.746)$ \\
\hline \multirow{2}{*}{ Age } & $0.612 * * *$ & $0.564 * * *$ & $0.654 * * *$ & -0.004 & -0.008 & -0.000 \\
\hline & $(6.525)$ & $(3.939)$ & $(6.516)$ & $(0.746)$ & $(0.913)$ & $(0.073)$ \\
\hline \multirow[t]{2}{*}{ Hispanic } & 0.535 & 0.699 & 0.612 & 0.026 & 0.055 & 0.011 \\
\hline & $(1.428)$ & $(1.329)$ & $(1.472)$ & $(1.104)$ & $(1.550)$ & $(0.438)$ \\
\hline \multirow[t]{2}{*}{ Black } & $0.981 * * *$ & 0.225 & $2.021 * * *$ & $0.045^{* *}$ & 0.020 & $0.085^{* * *}$ \\
\hline & $(3.431)$ & $(0.494)$ & $(4.714)$ & $(2.297)$ & $(0.632)$ & $(3.174)$ \\
\hline \multirow[t]{2}{*}{ Other race } & 0.566 & $1.910 *$ & 0.087 & 0.042 & 0.129 & -0.000 \\
\hline & $(1.223)$ & $(1.683)$ & $(0.161)$ & $(0.904)$ & (1.153) & $(0.021)$ \\
\hline \multirow[t]{2}{*}{ Male } & $0.763 * * *$ & --- & --- & $0.061 * * *$ & --- & --- \\
\hline & $(4.913)$ & $(---)$ & $(---)$ & $(5.411)$ & $(---)$ & $(---)$ \\
\hline \multirow[t]{2}{*}{ Family Income } & $-0.038 * *$ & -0.029 & -0.041 & -0.002 & -0.001 & $-0.003 * *$ \\
\hline & $(2.130)$ & $(1.284)$ & (1.642) & (1.597) & $(0.668)$ & $(2.469)$ \\
\hline \multirow[t]{2}{*}{ Income missing } & $-0.617 * * *$ & $-0.781 * *$ & -0.352 & $-0.044 * * *$ & $-0.064 * * *$ & -0.018 \\
\hline & $(2.647)$ & $(2.408)$ & $(1.158)$ & $(3.055)$ & $(2.644)$ & $(1.196)$ \\
\hline \multirow[t]{2}{*}{ Mother overweight } & $0.972 * * *$ & $1.261 * * *$ & $0.617 * * *$ & $0.041 * * *$ & $0.056 * * *$ & 0.016 \\
\hline & $(5.554)$ & $(4.734)$ & $(2.914)$ & $(3.408)$ & $(2.587)$ & $(1.491)$ \\
\hline \multirow[t]{2}{*}{ Mother obese } & $2.028 * * *$ & $1.512 * * *$ & $2.470 * * *$ & $0.128 * * *$ & $0.118 * * *$ & $0.138 * * *$ \\
\hline & $(6.989)$ & (3.219) & $(6.578)$ & $(6.100)$ & $(3.524)$ & $(4.290)$ \\
\hline \multirow[t]{2}{*}{ Mother employed } & 0.177 & 0.215 & 0.181 & 0.016 & 0.019 & 0.014 \\
\hline & $(0.821)$ & $(0.669)$ & $(0.725)$ & $(1.261)$ & $(0.976)$ & $(1.085)$ \\
\hline \multirow[t]{2}{*}{ Fast-food restaurants } & 0.222 & 0.096 & 0.069 & -0.003 & -0.001 & -0.007 \\
\hline & $(0.940)$ & $(0.264)$ & $(0.256)$ & $(0.243)$ & $(0.021)$ & $(0.558)$ \\
\hline \multirow[t]{2}{*}{ Full-service restaurants } & -0.069 & -0.178 & 0.041 & 0.007 & -0.003 & 0.019 \\
\hline & $(0.606)$ & $(1.184)$ & $(0.260)$ & $(0.533)$ & $(0.207)$ & $(1.106)$ \\
\hline \multirow[t]{2}{*}{ Cigarette price } & 0.247 & -0.044 & 0.757 & 0.039 & 0.017 & $0.073 * *$ \\
\hline & $(0.474)$ & $(0.054)$ & $(1.151)$ & $(1.173)$ & $(0.371)$ & $(2.403)$ \\
\hline \multirow[t]{2}{*}{ Government } & -0.441 & 0.832 & -0.140 & -0.028 & -0.055 & $0.155^{*}$ \\
\hline & $(0.591)$ & $(0.151)$ & $(1.419)$ & $(1.265)$ & $(0.300)$ & $(1.731)$ \\
\hline \multirow[t]{2}{*}{ Private } & 0.207 & $-0.765 * *$ & 0.585 & -0.063 & $0.006 * *$ & $-0.183^{*}$ \\
\hline & (1.610) & $(2.198)$ & $(0.312)$ & $(0.138)$ & $(2.071)$ & $(1.665)$ \\
\hline \multirow[t]{2}{*}{ Restaurant } & $-0.622 * *$ & 0.144 & 1.360 & -0.005 & 0.028 & -0.024 \\
\hline & $(1.970)$ & $(0.108)$ & $(1.136)$ & $(0.392)$ & $(0.360)$ & $(0.706)$ \\
\hline \multirow[t]{2}{*}{ Other } & 1.097 & -0.123 & -2.667 & $0.067 * *$ & 0.023 & -0.071 \\
\hline & $(0.484)$ & $(1.241)$ & $(1.281)$ & $(1.987)$ & $(0.107)$ & $(1.368)$ \\
\hline \multirow[t]{2}{*}{ Full-service restaurant price } & 0.024 & 0.029 & 0.017 & -0.002 & -0.008 & -0.003 \\
\hline & $(0.291)$ & $(0.237)$ & $(0.162)$ & $(0.348)$ & $(0.939)$ & $(0.250)$ \\
\hline \multirow[t]{2}{*}{ Fast-food restaurant price } & $-1.406^{* *}$ & -1.378 & $-1.429 *$ & -0.027 & -0.022 & -0.037 \\
\hline & $(2.063)$ & $(1.328)$ & (1.819) & $(0.662)$ & $(0.379)$ & $(0.766)$ \\
\hline Food at home price & -0.170 & $-1.910 *$ & 1.051 & 0.016 & -0.128 & 0.121 \\
\hline & $(0.155)$ & $(1.676)$ & $(0.581)$ & $(0.146)$ & $(0.920)$ & $(1.003)$ \\
\hline Sample size & 6,818 & 3,527 & 3,291 & 6,818 & 3,527 & 3,291 \\
\hline R-squared & 0.192 & 0.193 & 0.235 & 0.098 & 0.106 & 0.127 \\
\hline
\end{tabular}

${ }^{\text {a }}$ All regressions are weighted by NLSY sampling weights. T-ratios are reported in parentheses. Regressions are clustered by DMA. Regressions also include year and DMA fixed effects. Intercepts are not shown. *** Significant at the $1 \%$ level (two tailed test). ** Significant at the 5\% level (two tailed test). * Significant at the $10 \%$ level (two tailed test). 